\title{
The fossil rodent faunas of the localities Alcoy 2C and 2D (Alcoy Basin, Spain). Implications for dating the classical locality of Alcoy-Mina
}

\section{Las faunas de roedores fósiles de los yacimientos Alcoy 2C y 2D (Cuenca de Alcoy, España). Implicaciones para la datación de la localidad clásica de Alcoy-Mina}

\author{
S. Mansino ${ }^{1 *}$, I. Fierro ${ }^{2}$, F.J. Ruiz-Sánchez ${ }^{1}$, P. Montoya ${ }^{1}$ \\ ${ }^{1}$ Departament de Geologia, Universitat de València, Doctor Moliner 50, 46100 Burjassot, Spain \\ samuel.mansino@uv.es; francisco.ruiz@uv.es; plinio.montoya@uv.es. \\ ${ }^{2}$ Museo Paleontológico de Elche (MUPE), Plaça de Sant Joan 3, 03203 Elche, Spain \\ i.fierro@cidarismpe.org. \\ *Corresponding author
}

Received: 29/04/2011 / Accepted: 12/04/2013

\begin{abstract}
In the Gormaig area (Alcoy basin, SE Spain) a number of fossil mammal localities are known, of which only the classic site of Alcoy-Mina, known since the mid-19th century, has yielded remains of macrofauna. In the vicinity of this site are the localities of Alcoy-2C (AL2C) and Alcoy-2D (AL2D), probably representing the levels of Alcoy-Mina. The faunal assemblage allows dating the AL2C and AL2D localities as Early Pliocene (end of the Early Ruscinian or early-late Ruscinian boundary, MN14-MN15). Several taxa (Pliopetaurista and Glis) are thought to have affinities for humid and close biotopes.
\end{abstract}

Keywords: Rodentia, Pliocene, Ruscinian, Alcoy basin, Spain

Resumen

En el área del Gormaig (cuenca de Alcoy, SE España), se conocen toda una serie de yacimientos de mamíferos fósiles, de los cuáles tan sólo la localidad clásica de Alcoy-Mina, conocida desde mediados del siglo XIX, ha aportado restos de macrofauna. En las proximidades de esta localidad se encuentran los yacimientos de Alcoy-2C (AL2C) y Alcoy-2D (AL2D), probablemente representando los niveles fosilíferos de Alcoy-Mina. La asociación faunística encontrada en AL2C y AL2D permite la datación de estas localidades como pertenecientes al Plioceno inferior (fin del Rusciniense inferior o límite Rusciniense inferior-superior, zona MN14-MN15). Varios taxones (Pliopetaurista y Glis) se consideran indicadores de biotopos cerrados de carácter húmedo.

Palabras clave: Rodentia, Plioceno, Rusciniense, Cuenca de Alcoy, España

\section{Introduction}

In this paper we describe the rodent faunas from the fossil sites Alcoy-2C and Alcoy-2D (AL2C and AL2D), located in the western margin of the lacustrine basin of Alcoy (SE Spain). This basin belongs to the inner Prebetic of the Betic chain, and is surrounded by the mountain ranges of Menejador, Mariola and Benicadell (Fig. 1). 
Previous geological studies of this area were carried out by Durand Delga et al. (1964), Montenat (1973: 10091014, Fig.153) and Aguirre et al. (1975). More recently, the Alcoy basin has been studied by Pierson d'Autrey (1987).

In the Gormaget ravine area alluvial deposits are found in a statigraphical sequence made up of red conglomerates with grey marlstones intercalations that contain lenticular lignitic sediments (Santisteban et al., 1997). A more modern revision allows to differentiate between a higher set of red conglomerates and a lower one. A number of vertebrate localities are found in this sector (Fig. 1), of which only the historic site of Alcoy-Mina, known since the mid-19th century, has yielded remains of large mammals (Montoya et al., 2006a). Hitherto have been cited in this area the micromammal sites of AlcoyBarranco (Thaler et al., 1965; Adrover, 1969), Alcoy-N (López Martínez, 1989), Alcoy-4B (Freudenthal et al., 1998), Alcoy-2 (Esteban Aenlle and Lacomba, 1988) and Alcoi Cotes Altes-2 (Mansino et al., 2009). The suggested age for these localities ranges between MN13 and MN16, i.e., from terminal Miocene to upper Pliocene. On the other hand, new field work undertaken by the Department of Geology of the Universitat de València has resulted in the discovery of the new micromammal localities which are the subject of this study. They are in the same area where Esteban Aenlle and Lacomba (1988) cited the site of Alcoy-2, in the vicinity of a pithead of the former lignite mine (Alcoy-Mina) that has yielded macromammal remains since the mid-19th century (Gervais, 1853). Four new fossiliferous levels were localized, named AL2A, B, C and D, probably close to Alcoy-2. The resulting sampling of these levels showed that two of them, AL2A and AL2B, were sterile, while AL2C and AL2D yielded a promising richness of micromammal remains. The situation of AL2C and AL2D (Fig. 2), proximity and dip slope of these levels seem to allow correlation with the lignite levels of Alcoy-Mina and to precise the age of the latter classic locality (Montoya et al., 2006a). The fossil remains recovered from AL2C and AL2D have been compared with the collection from Alcoy-2 housed at the Universidad Complutense de Madrid (UCM, Spain), of which a preliminary faunal list was published by Esteban Aenlle and Lacomba (1988). In this paper we describe the rodent faunas from AL2C and AL2D, and discuss their bio-chronostratigraphic and paleoecologic implications.

\section{Material, methods and abbreviations}

Since 2005 , nearly $1 \mathrm{Tm}$ of sediment has been extracted from AL2C and AL2D. The recovered fossils are kept in the Museu de Geologia de la Universitat de València
(MGUV) with the acronyms AL2C- and AL2D-, respectively. The nomenclature and measurement methods are those of Martín-Suárez and Freudenthal (1993) for the family Muridae, Mein and Freudenthal (1971) for the Cricetidae, Daams (1981) and Freudenthal (2004) for the Gliridae, Weerd (1979), Adrover (1986) for the Trilophomyidae and Cuenca-Bescós (1988) and Reumer and van de Hoek Ostende (2003) for the Sciuridae. Measurements $(\mathrm{Lx} \mathrm{W})$ are in tenths of millimetres and were taken on a Leica $\mathrm{MZ7}_{5}$ binocular microscope, by means of displacement of a mechanical stage, connected to a Sony Magnescale measuring equipment. The lower teeth are indicated as $\mathbf{m} \mathbf{1}, \mathbf{m} \mathbf{2}$ and $\mathbf{m} 3$, the upper teeth as M1, M2 and M3 and the deciduous elements as D4.

Abbreviations.- AL2C, Alcoy-2C, AL2D, Alcoy-2D and AL2D'08, sample of Alcoy-2D taken in 2008 (this paper); BRA, Brácana; CAC, Cacín; CLC, Calicasas; DHS, Dehesa; H, height; MNA, Mina; PUR, Purcal; TCH, Tollo de Chiclana; MN, European Neogene land mammal units; $\mathbf{L}, \mathbf{W}$, length and width, respectively; L1, length of the occlusal surface; L2, total length (base of the crown); UCM, Universidad Complutense de Madrid; SCSIE (UV), Servei Central de support a la Investigació Experimental de la Universitat de Valéncia.

\section{Geological setting}

In the context of the Betic Range, Neogene postorogenic basins provide an important stratigraphic log. This information is essential to understand the final evolution on the Atlantic-Mediterranean communication. The closure of the seaway and the isolation of the basins are diachronic, so marine to continental transition takes form in different times and depends on its geographical location.

Isolation of the sea in the North Prebetic basins of Alicante was very early (Tortonian), and marine sediments are only represented in the Unit I of Viseras et al. (2004). First continental deposits belong to Unit II of the same authors, and are represented by alluvial fan facies in the margin and fluvio-lacustrine facies in the centre. In this context, the Miocene-Pliocene transition takes place in a continental environment (Aguirre et al., 1975).

The deposits of Alcoy basin have a very important role to study the paleoenvironmental evolution of this area since they provide interesting fossil sites. According to Ballesteros et al. (2007), the continental fossil sites in lignite deposits (like Alcoy Mina) belong to fluvial conglomerates, silts and clays unit, inside sintema $\mathrm{V}$ of the same authors. This sintema covers, in angular discordance, different Paleogene and Miocene units, so all the studied deposits are discordant with older material and its direction and dip are related with a normal fault (Ballesteros et al., 2007). 
From a geomorphologic point of view, the entire studied area (Alcoy Mina environment) is an ancient landslide. The analysis of aerial photography provides enough information to support this hypothesis. This landslide, which occurred prior to mine development and land terracing, allows still recognizing the main escarpment and its right and left flanks. Human activity and the passing of time have contributed to erase part of this natural phenomenon, although part of its vertical activity (Pedraza,
1996) and stratigraphic information can still be deduced. Fieldwork is really complicated due to the extent of cultivation terraces, soil development and escarpment. It has been possible to obtain synthetic statigraphic information for more than 27 meters in a series of over 50 (Fig. 2). This series includes materials located very close to the outcrop of Alcoy-Mina. Only a few meters of this 27 are in well exposed outcrops. To obtain the stratigraphic data presented in figure 2 we dug some trenches in different
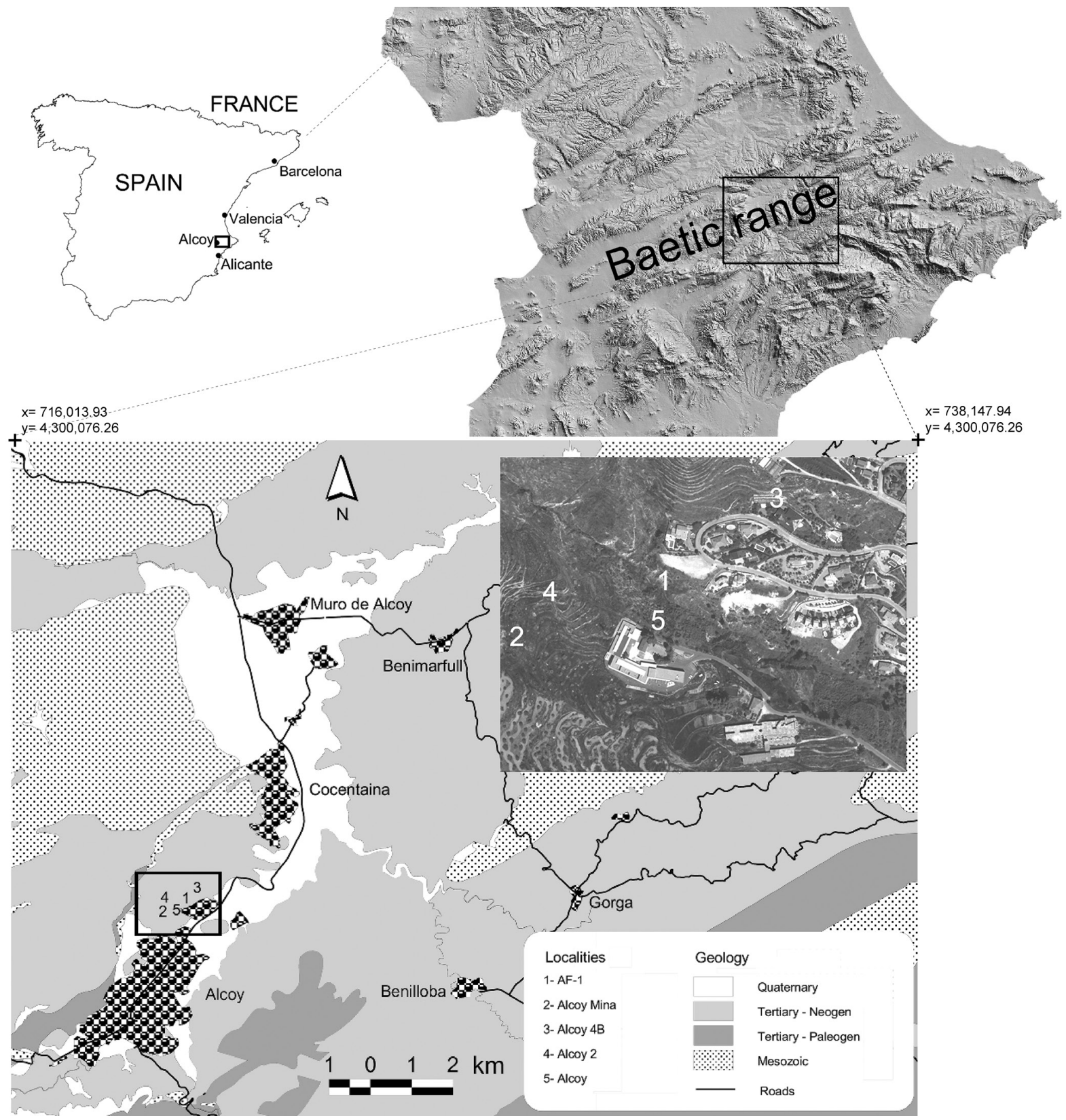

Fig. 1.- Geographic and geological setting of the Alcoy Basin, showing the location of the outcrops of the Gormaget ravine (1 to 5 fossil levels; for acronym, see legend). The location of other fossil localities studied previously is also shown: Alcoy (Adrover,1968), Alcoy-2 (Esteban Aenlle and Lacomba, 1988), Alcoy-4B (Freudenthal et al., 1998), Alcoy-Mina (Montoya et al., 2006a) and AF-1 (Mansino et al., in prep.).

Fig. 1.- Esquema geográfico y geológico de la Cuenca de Alcoy, mostrando la localización de los afloramientos del barranco del Gormaget (niveles fosilíferos del 1 al 5; para acrónimo ver leyenda). Se muestra además, la localización de las localidades previamente estudiadas: Alcoy (Adrover,1968), Alcoy-2 (Esteban Aenlle and Lacomba, 1988), Alcoy-4B (Freudenthal et al., 1998), Alcoy-Mina (Montoya et al., 2006a) y AF-1 (Mansino et al., in prep.). 
Fig. 2.- Lithostratigraphic $\log$ of the Alcoy-Mina surroundings, with the stratigraphical position of the microvertebrate-bearing localities of the AL2C y AL2D. Scale in meters.

Fig. 2.- Columna litoestratigráfica de los alrededores de Alcoy-Mina, con la posición estratigráfica de los yacimientos de microvertebrados de AL2C y AL2D. Escala en metros.

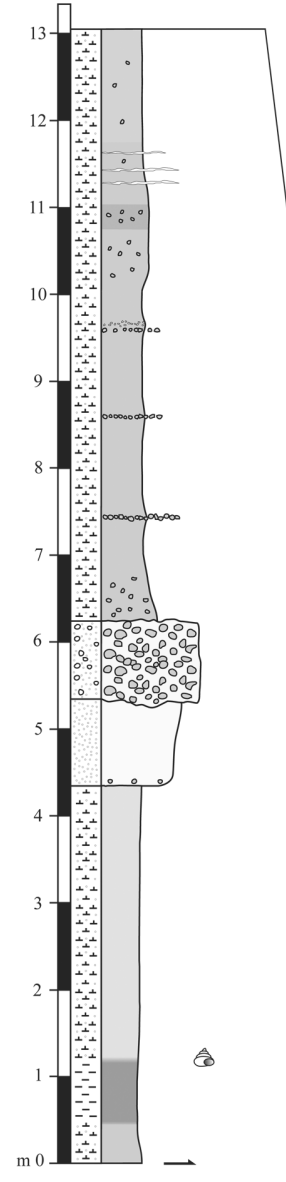

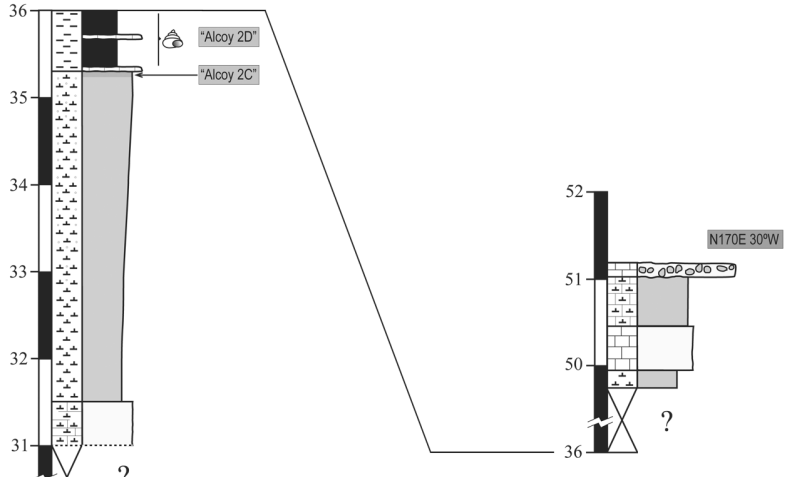
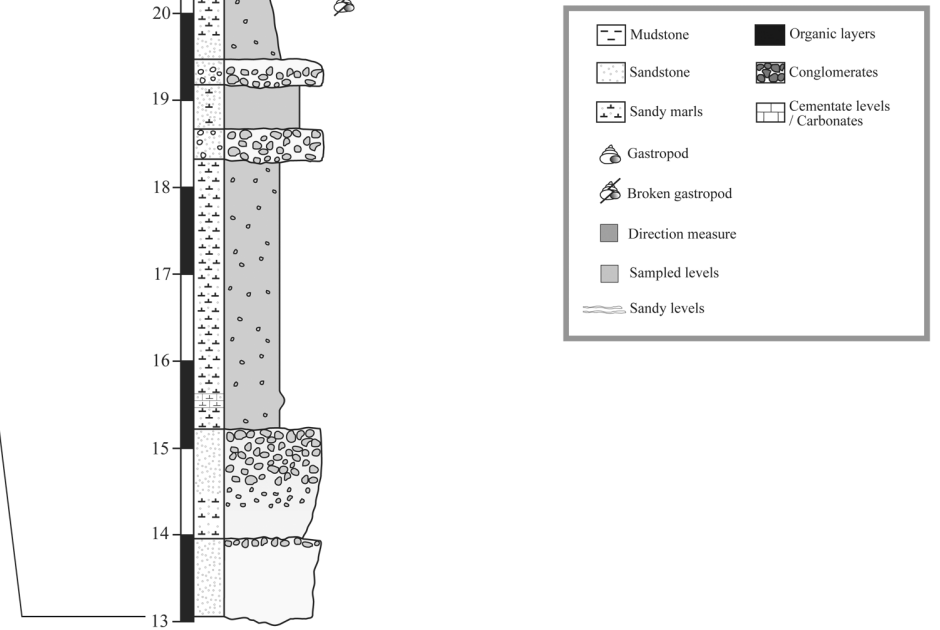

by Montenat (1973: 1009-1014, fig. 153) of a geological section carried out in the vicinity of Alcoy by Durand Delga et al. (1964).

In the studied area, the sandy-marls deposits with gray to brownish colors, which may be several meters thick, are generally dominant. Isolated pebbles in marls or sandy to conglomerate linear intercalations are common. Besides, conglomerate levels are relatively common, and reach a thickness of a meter or even higher.

These conglomerates strata are light colored (often yellow), with a sandy matrix, and often lack internal structure. In some of them we observe coarsening-upward pebbles and minor erosive base. They differ from those in the top of the Gormaget ravine (stratigraphically higher), which have a reddish matrix, a bigger average size of the pebbles and a greater thickness of the strata.

The assembly described has an approximate dip slope of $30^{\circ}$ to the West, and it has been possible to identify several faults, although its importance is unknown. Throughout the series there are only two organic layers, AL2D (Fig. 2) and Alcoy-Mina inferior, being the lower one of little importance and without fossil remains (lower part of column presented in figure 2). However, it must be noted that the nature of more than 20 meters of the
Studies on the stratigraphy of the Neogene sediments from Alcoy are very scarce. We can mention the revision

\subsection{Stratigraphy and sedimentology}


statigraphic column is not clear because of the great plant and soil development.

AL2D is more than of 60 centimeters thick, only visible in a small outcrop. At first sight we can find abundant gastropod fragments. In the lower part of AL2D there is a fine clay level with intense ochre color (AL2C). In addition, in the middle and lower part of the organic layer we detect two light colored marly limestone levels.

AL2D seems to be a paleosoil of organic nature (histosol) which must have developed in a flooded area of low energy. The lenticular shape of organic levels in the studied area probably is related to the existence of depressions of limited extension in which some drainage occurred.

Alluvial facies like the ones present in the context of Alcoy-Mina are located in the margins of the basin. Massive conglomerates have been interpreted as subaerial deposits, formed by gravitational flows in mass (Santisteban et al., 1997).

The bulk of sediments from alluvial plains are overbank deposited during the high floods, when the system often inundates extensive areas (Kukal, 1971). We can think that alluvial systems are formed, to a large degree, by fluviatile processes with the influence of mudflows produced by the downslope movement of solid debris. The organic marls represent lacustrine deposits that could be interpreted like expansive periods of a lake or be placed between river branches, at the margins of alluvial plains or in an area between two fans. In this sense, organic deposits collect vertebrate remains representing the different paleoenvironment around them.

\section{Systematic paleontology}

Order Rodentia Bowdich, 1821

Family Muridae Illiger, 1811

Genus: Apodemus Kaup, 1826

Apodemus atavus Heller, 1936 (Fig. 3, 1-5)

Localities: AL2C, AL2D

Material: $3 \mathrm{~m} 1$ (AL2D-25, AL2D-26, AL2D-41), 3 m2 (AL2D-68, AL2D-69, AL2D-360), 6 m3 (AL2C-51, AL2C-53, AL2C-61, AL2D-74, AL2D-92, AL2D-96), 4 M2 (AL2C-30, AL2D-182 to AL2D-184), 3 M3 (AL2C40, AL2D-217, AL2D-218)

Measurements: see Table 1

\section{Description:}

$m 1$ : The tma is large, round and central. Symmetrical anteroconid, connected with the metaconid-protoconid pair by a narrow crest in one of the specimens. Large labial cingulum, interrupted between the hypoconid and

\begin{tabular}{ccccccc} 
Element & Locality & Parameter & $\mathrm{n}$ & min. & mean & Max. \\
\hline \multirow{2}{*}{ m1 } & AL2D & L & 2 & 15.60 & 16.10 & 16.60 \\
& & W & 2 & 08.90 & 09.20 & 09.60 \\
m2 & \multirow{2}{*}{ AL2D } & L & 3 & 11.40 & 11.70 & 12.00 \\
& & W & 3 & 09.20 & 10.00 & 10.60 \\
m3 & AL2D & L & 3 & 11.10 & 11.60 & 11.90 \\
& & W & 3 & 09.10 & 10.20 & 11.60 \\
& AL2C & L & 2 & 10.60 & 11.00 & 11.50 \\
& & W & 2 & 10.00 & 10.30 & 10.60 \\
M2 & AL2D & L & 3 & 12.10 & 12.30 & 12.60 \\
& & W & 3 & 10.70 & 11.10 & 11.90 \\
& AL2C & L & 1 & - & 12.70 & - \\
& & W & 1 & - & 10.90 & - \\
M3 & AL2D & L & 2 & 09.40 & 09.45 & 09.50 \\
& & W & 2 & 09.50 & 09.60 & 09.80 \\
& AL2C & L & 1 & - & 11.00 & -
\end{tabular}

Table 1.- Measurements in tenths of a millimeter of the teeth of Apodemus atavus from the localities AL2C and AL2D. n= number of measurable specimens.

Tabla 1.- Medidas en décimas de milímetro de los dientes de Apodemus atavus de las localidades AL2C and AL2D. n= número de especímenes medibles.

protoconid. The $\mathrm{c} 1$ is larger than both the tma and the posterior heel. In one of the specimens this cusp seems to have a very small $\mathrm{c} 0$ attached to its posterior side. There is an accessory cusp equivalent in size to the $\mathrm{c} 1$ in contact with the protoconid. The posterior heel is big, round and shifted towards the lingual side of the tooth.

$m 2$ : The anterolabial cusp is large and comma-shaped; in advanced stages of wear the connection to the protoconid is very evident. Well-developed labial cingulum, separated from the protoconid and hypoconid. There is a large $\mathrm{c} 1$ and an accessory cusp, which is highly reduced in one of the specimens. Round or oval posterior heel.

$m 3$ : The anterolabial cusp is absent. No longitudinal crest. One of the teeth has a small c1, absent in the others.

M2: The $t 1$ is large. The $\mathrm{t} 3$ is small and round. The $\mathrm{t} 7$ is oval or round and separated from $t 4$. The t6 is connected to $t 9$. The $t 12$ is connected to $t 8$ and separated from $t 9$.

\section{Discussion:}

Apodemus dominans Kretzoi, 1959, and A. atavus have been considered synonyms by several authors (MinwerBarakat, 2005; Minwer-Barakat et al., 2005; García-Alix, 2006, García-Alix et al., 2008b). The specimens from AL2C and AL2D present some typical features of $A$. atavus, such as the metaconid linked to the lingual lobe of the anteroconid by a low crest (Fig. 3,1), the large posterior heel of the $\mathrm{m} 2$ that usually protrudes over the outline of the tooth (Fig. 3, 2), and the t7-t4 separation 
which is deep (at the base of the crown) or of medium height in M2 (Fig. 3, 4). We have discarded these molars as belonging to A. gudrunae van de Weerd, 1976, because of the individualized 77 (Fig. 3, 4) and smaller size. The measurements of our specimens (Table 1) match a smallsized Apodemus, being similar to those of A. dominans from Sarrión, Orrios 3, Arquillo 3, Villalba Alta and A1dehuela (Adrover, 1986), Escorihuela, Orrios, Csarnóta 2 (van de Weerd, 1976), Moreda-1A, Belmez-1 and Moreda-1B (Castillo, 1990), Alozaina (Aguilar et al., 1993) Mont-Hélène (Aguilar et al., 1986), Concud Estación 1 and 3, and Concud Pueblo 3 (Adrover et al., 1988). These measurements also fall within the range of variation of $A$. atavus from the localities of TCH-1, 1B, 3 and 13 (Minwer-Barakar et al., 2005), being slightly smaller than those from PUR-7, PUR-13, CLC-3, CLC-3B, CLC4B, AGU-1C and DHS-1 (García-Alix et al., 2008b).

Apodemus gorafensis Ruiz Bustos, Sesé, Dabrio, Peña and Padial, 1984 (Fig. 3, 6-11)

Locality: AL2C, AL2D

Material: 1m1 (AL2D-17), $5 \mathrm{~m} 2$ (AL2D-50, AL2D51, AL2D-56, AL2D-62, AL2D-64), 6 m3 (AL2C-48, AL2D-72, AL2D-91, AL2D-93, AL2D-136, AL2D-220), 6 M1 (AL2C-20 to AL2C-22, AL2D-131, AL2D-133, AL2D-134), 6 M2 (AL2C-37, AL2D-142, AL2D-176, AL2D-177, AL2D-181, AL2D-351), 4 M3 (AL2D-206, AL2D-212, AL2D-213, AL2D-222)

Measurements: see Table 2

\section{Description:}

$m 1$ : The only specimen recovered is in an advanced stage of wear. There is a large tma. The tooth has a large $\mathrm{c} 1$ and two accessory cusps. The posterior heel cannot be observed. Two roots.

$m 2$ : Isolated anterolabial cusp. Well-developed labial cingulum. There is a large $\mathrm{c} 1$, and an accessory cusp may also be present. Round or oval posterior heel.

m3: Highly reduced anterolabial cusp. No longitudinal crest. One of the specimens has a small c1.

M1: The $\mathrm{t} 1$ is situated posteriorly with respect to the $\mathrm{t} 3$. The connection between $\mathrm{t} 1$ and $\mathrm{t} 2$ is very low. There is neither $\mathrm{t} 1$ bis nor $\mathrm{t} 2$ bis. All the teeth have a small posterior spur in the $\mathrm{t} 3$ directed towards the $\mathrm{t} 6$. One specimen has a small distal spur in the $\mathrm{t} 1$ directed towards the $\mathrm{t} 5$. The valley between $\mathrm{t} 3$ and $\mathrm{t} 6$ is very deep and wide. The $\mathrm{t} 4, \mathrm{t} 5, \mathrm{t} 6, \mathrm{t} 7$ and $\mathrm{t} 9$ are connected. The $\mathrm{t} 12$ is round and medium-sized, connected to the posterolabial part of the t8. There are four roots.

\begin{tabular}{ccccccc} 
Element & Locality & Parameter & $\mathrm{n}$ & min. & mean & Max. \\
\hline \multirow{2}{*}{ m1 } & AL2D & L & 1 & - & 22.50 & - \\
& & W & 1 & - & 13.60 & - \\
m2 & AL2D & L & 5 & 16.00 & 17.20 & 17.80 \\
& & W & 5 & 13.70 & 15.40 & 16.60 \\
m3 & AL2D & L & 3 & 12.90 & 13.10 & 13.30 \\
& & W & 5 & 11.30 & 12.20 & 13.20 \\
& AL2C & L & 1 & - & 13.60 & - \\
& & W & 1 & - & 12.80 & - \\
M1 & AL2D & L & 1 & - & 24.30 & - \\
& & W & 3 & 13.30 & 13.80 & 14.30 \\
& AL2C & L & 2 & 22.40 & 22.50 & 22.70 \\
& & W & 2 & 13.20 & 13.25 & 13.30 \\
M2 & AL2D & L & 4 & 14.60 & 15.00 & 15.70 \\
& & W & 5 & 12.40 & 13.00 & 13.60 \\
& AL2C & L & 1 & - & 14.90 & - \\
& & W & 1 & - & 15.20 & - \\
M3 & AL2D & L & 4 & 11.30 & 11.60 & 12.00 \\
& & W & 4 & 09.50 & 10.70 & 11.50
\end{tabular}

Table 2.- Measurements in tenths of a millimeter of the teeth of Apodemus gorafensis from the localities AL2C and AL2D. $\mathrm{n}=$ number of measurable specimens.

Tabla 2.- Medidas en décimas de milímetro de los dientes de Apodemus gorafensis de las localidades AL2C and AL2D. n= número de especímenes medibles.

M2: Oval or round $\mathrm{t} 1$. The specimen from AL2C, which is very worn, and one molar from AL2D show a spur directed towards the $\mathrm{t} 4-\mathrm{t} 5$ intersection. The $\mathrm{t} 3$ is smaller than $\mathrm{t} 1$, and highly reduced in one tooth. The $\mathrm{t} 4$ and $\mathrm{t} 7$ are separated. The $t 6$ and $t 9$ are connected in the molars with an advanced stage of wear. The 12 is small and connected to the posterolabial part of $t 8$ and separated from $t 9$.

M3: The $\mathrm{t} 1$ isolated in two specimens. The $\mathrm{t} 3$ is absent. The $\mathrm{t} 4, \mathrm{t} 5$, $\mathrm{t} 6$ and $\mathrm{t} 8$ are connected.

\section{Discussion:}

During the Early and Middle Pliocene of Western Europe, two different lineages of Apodemus can be distinguished, a smaller form and a larger one (Martín-Suárez and Mein, 1998). In the Iberian basins there are a number of localities in which this situation occurs, in particular with $A$. atavus or $A$. aff. atavus and and A. gorafensis or $A$. aff. gorafensis. The coexistence of these two lineages has been recorded in the localities of Peralejos E (Adrover et al., 1988), Celadas 9 and La Gloria 4 (Adrover et al., 1993), from Teruel, PUR-4, PUR-13 and CLC-3B in the Granada basin (García-Alix et al., 2008b) (Fig. 4) and Alcoy (Esteban Aenlle and Lacomba, 1988) (Table 3). The specimens from AL2C and AL2D are bigger and 

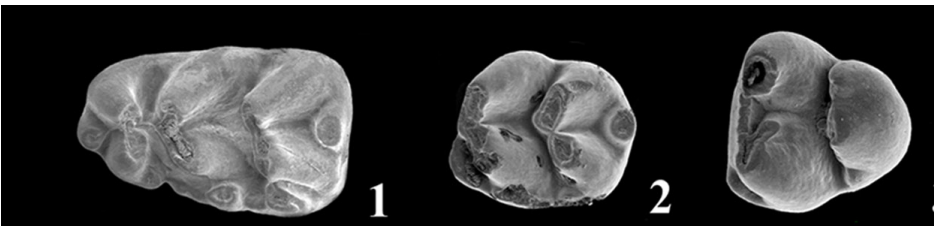

3

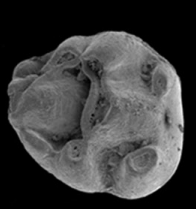

4

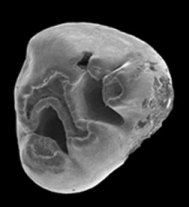

5

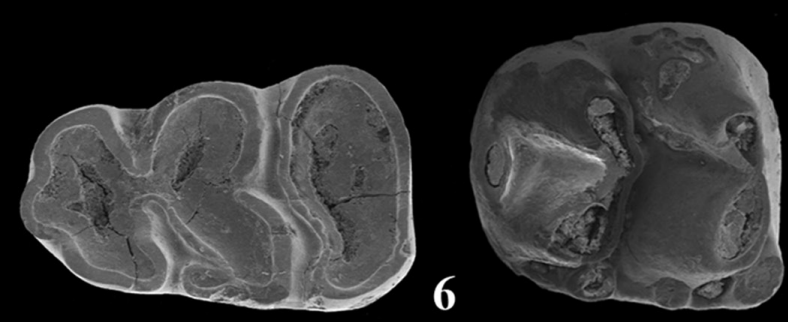

7

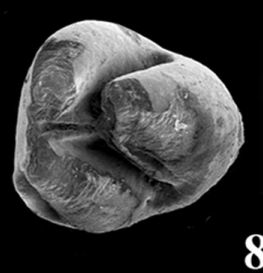

8
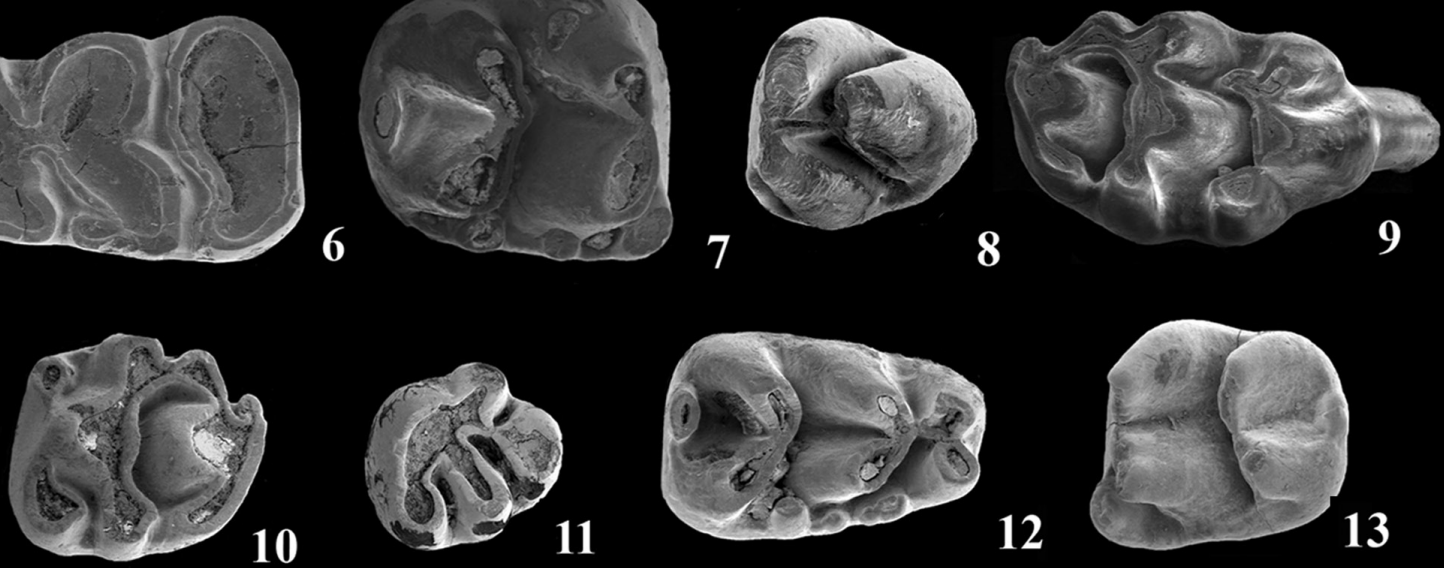

12

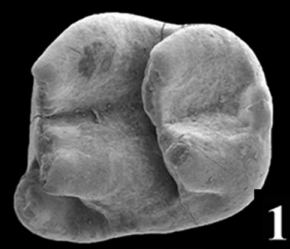

13
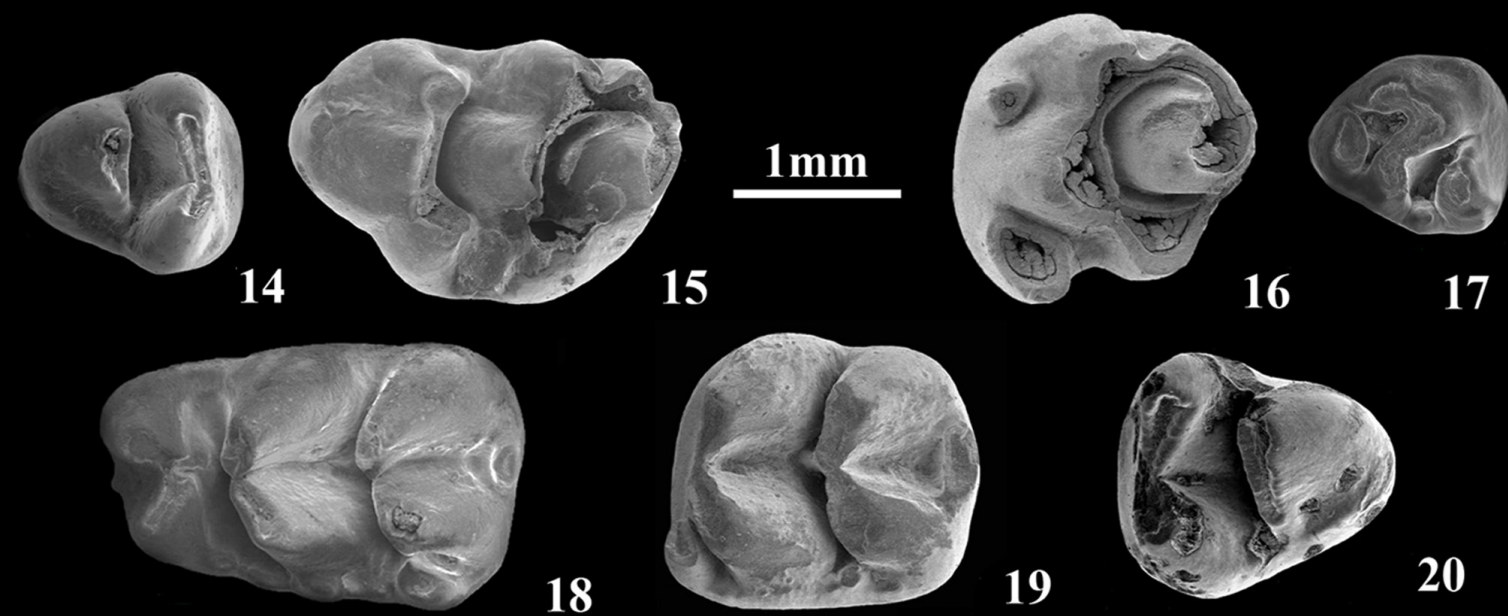

18

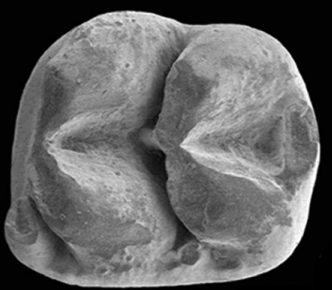

19

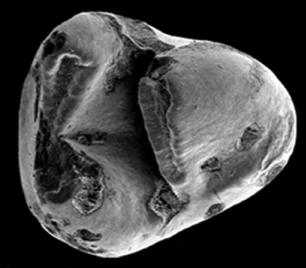

20

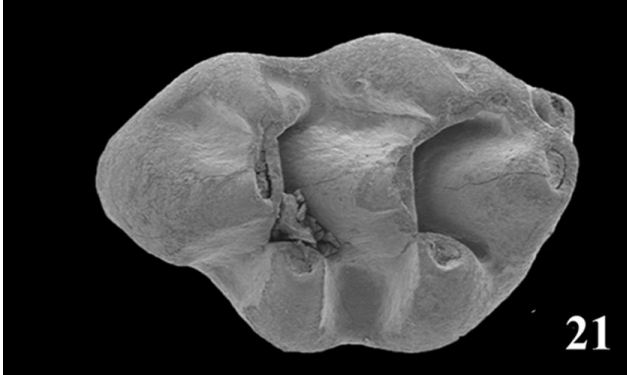

21
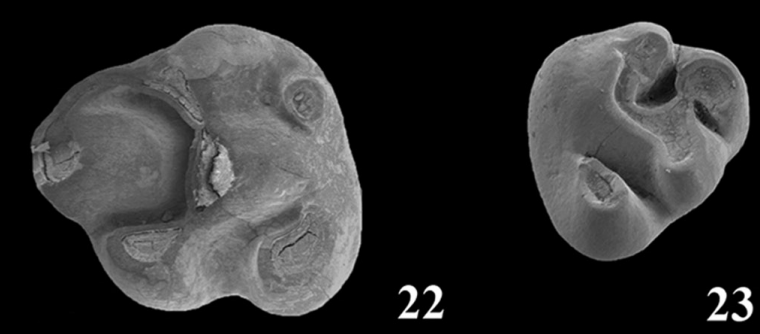

Fig. 3.- Rodent faunas from AL2C and AL2D (Alcoy basin, Spain). Apodemus atavus from AL2C and AL2D. 1, left m1, AL2D-25; 2, left m2, AL2D68; 3, left m3, AL2D-74; 4, right M2, AL2D-184; 5, left M3, AL2C-40. Apodemus gorafensis from AL2C and AL2D. 6, left m1, AL2D-17; 7, right m2, AL2D-50; 8, left m3, AL2C-48; 9, right M1, AL2C-20; 10, left M2, ALD-176; 11, left M3, AL2D-212. Paraethomys meini from AL2C and AL2D. 12, right m1, AL2D-21; 13, left m2, AL2D-66; 14, right m3, ALC-50; 15, left M1, AL2D-126; 16, left M2, AL2D-350; 17, right M3, AL2D216. Paraethomys aff. abaigari from AL2C and AL2D. 18, left m1, AL2D-1; 19, left m2, AL2C-48; 20, left m3, AL2C-49; 21, left M1, AL2D-101; 22, right M2, AL2C-28; 23, left M3, AL2D-194. Scale=1mm.

Fig. 3.- Faunas de roedores de AL2C y AL2D (Cuenca de Alcoy, España). Apodemus atavus de AL2C y AL2D. 1, m1 izquierdo, AL2D-25; 2, m2 izquierdo, AL2D-68; 3, m3 derecho, AL2D-74; 4, M2 derecho, AL2D-184; 5, M3 izquierdo, AL2C-40. Apodemus gorafensis de AL2C y AL2D. 6, $\mathrm{m} 1$ izquierdo, AL2D-17; 7, m2 derecho, AL2D-50; 8, m3 izquierdo, AL2C-48; 9, M1 derecho, AL2C-20; 10, M2 izquierdo, ALD-176; 11, M3 izquierdo, AL2D-212. Paraethomys meini de AL2C y AL2D. 12, m1 derecho, AL2D-21; 13, m2 izquierdo, AL2D-66; 14, m3 derecho, ALC-50; 15, M1 izquierdo, AL2D-126; 16, M2 izquierdo, AL2D-350; 17, M3 derecho, AL2D-216. Paraethomys aff. abaigari de AL2C y AL2D. 18, m1 izquierdo, AL2D-1; 19, m2 izquierdo, AL2C-48; 20, m3 izquierdo, AL2C-49; 21, M1 izquierdo, AL2D-101; 22, M2 derecho, AL2C-28; 23, M3 izquierdo, AL2D-194. Escala=1mm. 


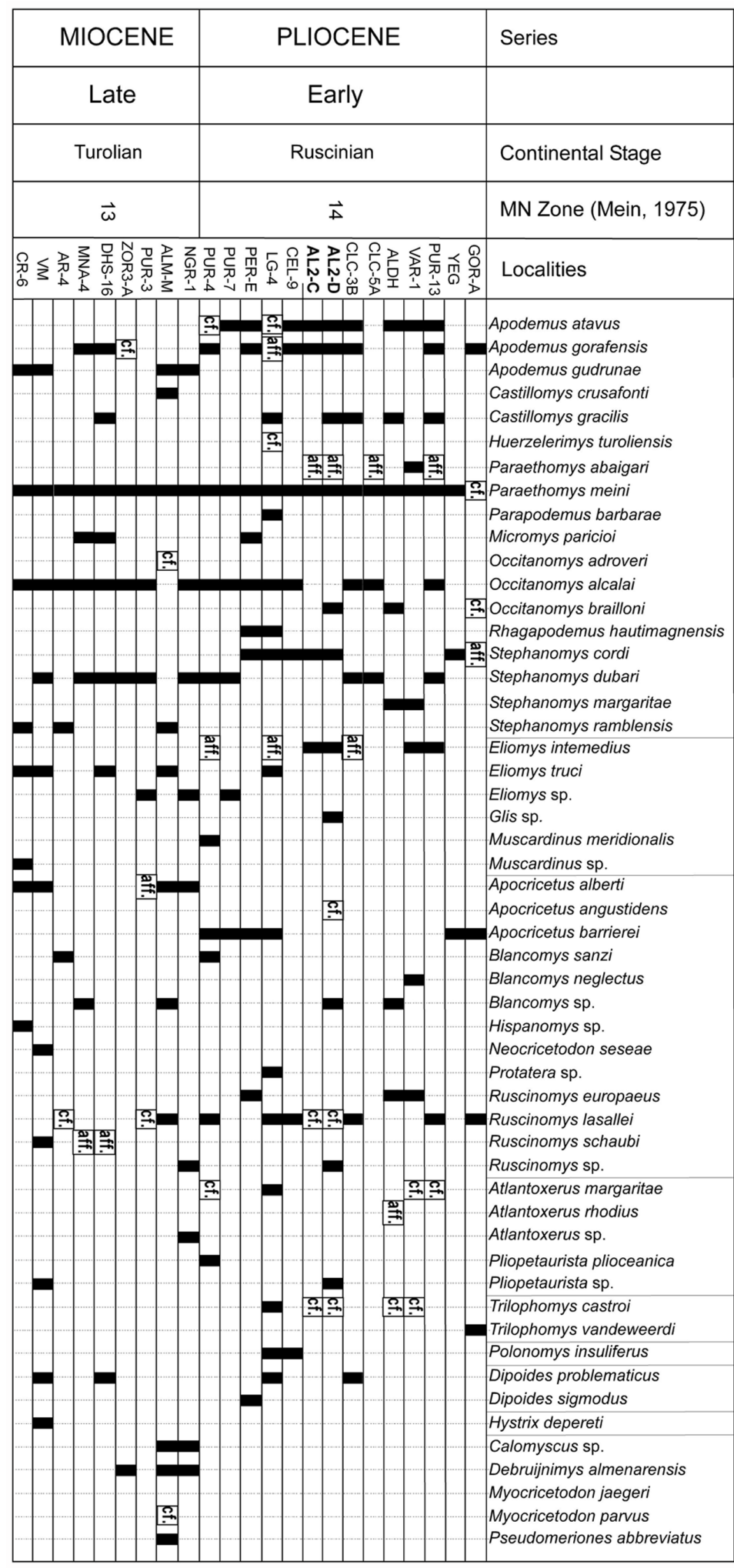

Fig. 4.- Distribution chart of the rodent species studied in this paper and, according to blibliography, of other species of similar age. Abbreviations: GOR-A, Gorafe-A (Ruiz-Bustos et al., 1984); YEG, Yeguas (Minwer-Barakat, 2005); PUR3, PUR-4, PUR-7, PUR-13, Purcal 3, 4, 7 and 13; CLC-3B, CLC-5A, Calicasas 3 B and 5A; DHS-16, Dehesa-16; MNA-4, Mina 4 (GarcíaAlix, 2006); VAR-1, Villalba Alta Río 1; ALDH, Aldehuela (Adrover, 1986); CEL-9, Celadas-9; LG-4, La Gloria-4; AR-4, Arquillo 4 (Adrover et al., 1993); PER-E, Peralejos-E (Mein et al., 1990); NGR-1, Negratín-1 (Minwer-Barakat et al., 2009); ALM-M, Almenara-M (Furió et al., 2005); ZOR-3A, Zorreras 3A (Martín-Suárez et al., 2000); VM, Venta del Moro (Montoya et al., 2006b); CR-6, Crevillente 6 (Martín-Suárez and Freudenthal, 1998). For the making of this table the following synonymies have been taken in account: Apodemus dominans as A. atavus; Castillomys crusafonti gracilis as C. gracilis; Paraethomys anomalus as P. meini; Stephanomys medius and Stephanomys donnezani cordii as $S$. cordii; Cricetus barrierei as Apocricetus barrierei; Cricetus kormosi and Apocricetus kormosi as Apocricetus alberti; Protatera almenarensis as Debruijnimys almenarensis.

Gliridae

Cricetidae

Fig. 4.- Cuadro de distribución de las especies de roedores estudiados en este trabajo y de otras especies de similar edad según la bibliografía. Abreviaciones: GOR-A, Gorafe-A (Ruiz-Bustos et al., 1984); YEG, Yeguas (Minwer-Barakat, 2005); PUR-3, PUR-4, PUR-7, PUR-13, Purcal 3, 4, 7 y 13; CLC-3B, CLC-5A, Calicasas 3 B y 5A; DHS-16, Dehesa-16; MNA-4, Mina 4 (García-Alix, 2006); VAR-1, Villalba Alta Río 1; ALDH, Aldehuela (Adrover, 1986); CEL-9, Celadas-9; LG-4, La Gloria-4; AR-4, Arquillo 4 (Adrover et al., 1993); PER-E, Peralejos-E (Mein et al., 1990); NGR-1 , Negratín-1 (Minwer-Barakat et al., 2009); ALM-M, Almenara-M (Furió et al., 2005); ZOR-3A, Zorreras 3A (Martín-Suárez et al., 2000) ; VM, Venta del Moro (Montoya et al., 2006b); CR-6, Crevillente 6 (Martín-Suárez and Freudenthal, 1998). Sinonimias tomadas en cuenta para confeccionar esta tabla: Apodemus dominans como A. atavus; Castillomys crusafonti gracilis como C. gracilis; Paraethomys anomalus como P. meini; Stephanomys medius y Stephanomys donnezani cordii como $S$. cordii; Cricetus barrierei como Apocricetus barrierei; Cricetus kormosi y Apocricetus kormosi como Apocricetus alberti; Protatera almenarensis como Debruijnimys almenarensis with a more developed 77 than $A$. gudrunae van de Weerd 1976, and smaller and with a more developed tma than $A$. jeanteti Michaux, 1967. Apodemus agustii Martín Suárez, 1988, differs from our material by its bigger tma, lack of stephanodonty in the upper molars and a funnel delimited by the anteroconid, protoconid and metaconid in the $\mathrm{m} 1$.
The the populations from AL2C and AL2D are consistent with the measurements and morphology of A. gorafensis of the collection from Gorafe-A, the type locality of the species (Ruiz Bustos et al., 1984), showing a relatively large tma and well-developed labial cingulum and t7. Our specimens are somewhat bigger than Apodemus 


Alcoy-2
(Esteban Aenlle and Lacomba, 1988)
Apodemus dominans
Apodemus gorafensis
Castillomys crusafonti gracilis
Paraethomys meini
Paraethomys jaegeri
-
Stephanomys medius
-
Ruscinomys aff. europaeus
Blancomys neglectus
Trilophomys castroi
-
-

AL2C
(This paper)
Apodemus atavus
Apodemus gorafensis
-
Paraethomys meini
Paraethomys aff. abaigari
-
Stephanomys cordii
Apocricetus cf. angustidens
Ruscinomys cf. lasallei
-
Trilophomys cf. castroi
Eliomys intermedius

AL2C

Apodemus atavus

Apodemus gorafensis

Paraethomys meini

Stephanomys cordii Apocricetus cf. angustidens

Trilophomys cf. castroi
Eliomys intermedius

\author{
AL2D \\ (This paper) \\ Apodemus atavus \\ Apodemus gorafensis \\ Castillomys gracilis \\ Paraethomys meini \\ Paraethomys aff. abaigari \\ Occitanomys brailloni \\ Stephanomys cordii \\ Apocricetus cf. angustidens \\ Ruscinomys cf. lasallei \\ Blancomys sp. \\ Trilophomys cf. castroi \\ Eliomys intermedius \\ Glis sp. \\ Pliopetaurista sp.
}

Table 3.- Faunal list of Alcoy-2 (Esteban Aenlle and Lacomba, 1988) compared with the faunal lists of the localities studied in this paper, AL2C and AL2D.

Tabla 3.- Lista faunística de Alcoy-2 (Esteban Aenlle and Lacomba, 1988) comparada con las listas faunísticas de los yacimientos estudiados en este trabajo, AL2C y AL2D.

aff. gorafensis from Peralejos E (Adrover et al., 1988), falling within the range of variation of $A$. aff. gorafensis from Celadas 9 and La Gloria 4 (Adrover et al., 1993). The mean measurements of the populations from AL2C and AL2D are slightly bigger than $A$. aff. gorafensis from PUR-23, being also very similar to those of $A$. gorafensis from PUR-4, PUR-24A, PUR 25, PUR-25A, MNA-2 and MNA-4 (García-Alix et al., 2008b).

Genus Paraethomys Petter, 1968

Paraethomys meini (Michaux, 1969) (Fig. 3, 12-17)

Localities: AL2C, AL2D

Material: $15 \mathrm{~m} 1$ (AL2C-1, AL2C-3, AL2C-43, AL2C45, AL2C-46, AL2C-58, AL2C-66, AL2D-15, AL2D-21 to AL2D-24, AL2D-40, AL2D-347), $6 \mathrm{~m} 2$ (AL2C-11, AL2C-12, AL2D-45, AL2D-58, AL2D-66, AL2D-67), 5 m3 (AL2C-50, AL2C-63, AL2D-83, AL2D-87, AL2D88, AL2D-90), 3 M1 (AL2D-126, AL2D-132, AL2D253) 4 M2 (AL2D-172, AL2D-178, AL2D-179, AL2D350), 8 M3 (AL2C-41, AL2C-62, AL2C-68, AL2D-210, AL2D-214 to AL2D-216, AL2D-352)

Measurements: see Table 4

\section{Description:}

m1: Absent tma. Slightly asymmetrical anteroconid. The connection between anteroconid and protoconidmetaconid pair is very low, and in some teeth a small round funnel can be observed. Medium-sized labial cingulum. One of the molars has an incipient longitudinal spur. There is a medium size round $\mathrm{c} 1$. The size and number of the accessory cusps is very variable, ranging from two to four. Reduced posterior heel.

$m 2$ : The anterolabial cusp is in contact with a moderately developed labial cingulum. Three of the specimens

\begin{tabular}{|c|c|c|c|c|c|c|}
\hline Element & Locality & Parameter & $\mathrm{n}$ & $\min$ & mean & Max. \\
\hline \multirow[t]{4}{*}{$\mathrm{m} 1$} & AL2D & $\mathrm{L}$ & 6 & 19.00 & 19.40 & 19.90 \\
\hline & & W & 6 & 11.60 & 12.00 & 12.50 \\
\hline & AL2C & $\mathrm{L}$ & 2 & 19.30 & 19.40 & 19.50 \\
\hline & & W & 4 & 11.40 & 11.90 & 12.40 \\
\hline \multirow[t]{4}{*}{$\mathrm{m} 2$} & AL2D & $\mathrm{L}$ & 4 & 14.10 & 14.70 & 15.10 \\
\hline & & W & 4 & 12.00 & 12.70 & 13.20 \\
\hline & AL2C & $\mathrm{L}$ & 2 & 13.60 & 14.50 & 15.50 \\
\hline & & W & 2 & 11.30 & 11.40 & 11.50 \\
\hline \multirow[t]{4}{*}{$\mathrm{m} 3$} & AL2D & $\mathrm{L}$ & 4 & 12.40 & 13.70 & 14.30 \\
\hline & & W & 4 & 11.20 & 12.10 & 12.90 \\
\hline & AL2C & $\mathrm{L}$ & 1 & - & 13.20 & - \\
\hline & & W & 1 & - & 12.70 & - \\
\hline \multirow[t]{2}{*}{ M1 } & AL2D & $\mathrm{L}$ & 1 & - & 22.40 & - \\
\hline & & W & 2 & 15.30 & 15.35 & 15.40 \\
\hline \multirow[t]{2}{*}{ M2 } & AL2D & $\mathrm{L}$ & 2 & - & 17.40 & - \\
\hline & & W & 3 & 15.50 & 16.10 & 16.70 \\
\hline \multirow[t]{4}{*}{ M3 } & AL2D & $\mathrm{L}$ & 5 & 10.40 & 11.20 & 12.60 \\
\hline & & W & 5 & 09.70 & 10.60 & 11.50 \\
\hline & AL2C & $\mathrm{L}$ & 3 & 12.20 & 12.70 & 13.30 \\
\hline & & W & 3 & 10.70 & 11.70 & 12.20 \\
\hline
\end{tabular}

Table 4.- Measurements in tenths of a millimeter of the teeth of Paraethomys meini from the localities AL2C and AL2D. $\mathrm{n}=$ number of measurable specimens.

Tabla 4.- Medidas en décimas de milímetro de los dientes de Paraethomys meini de las localidades AL2C and AL2D. n= número de especímenes medibles. 


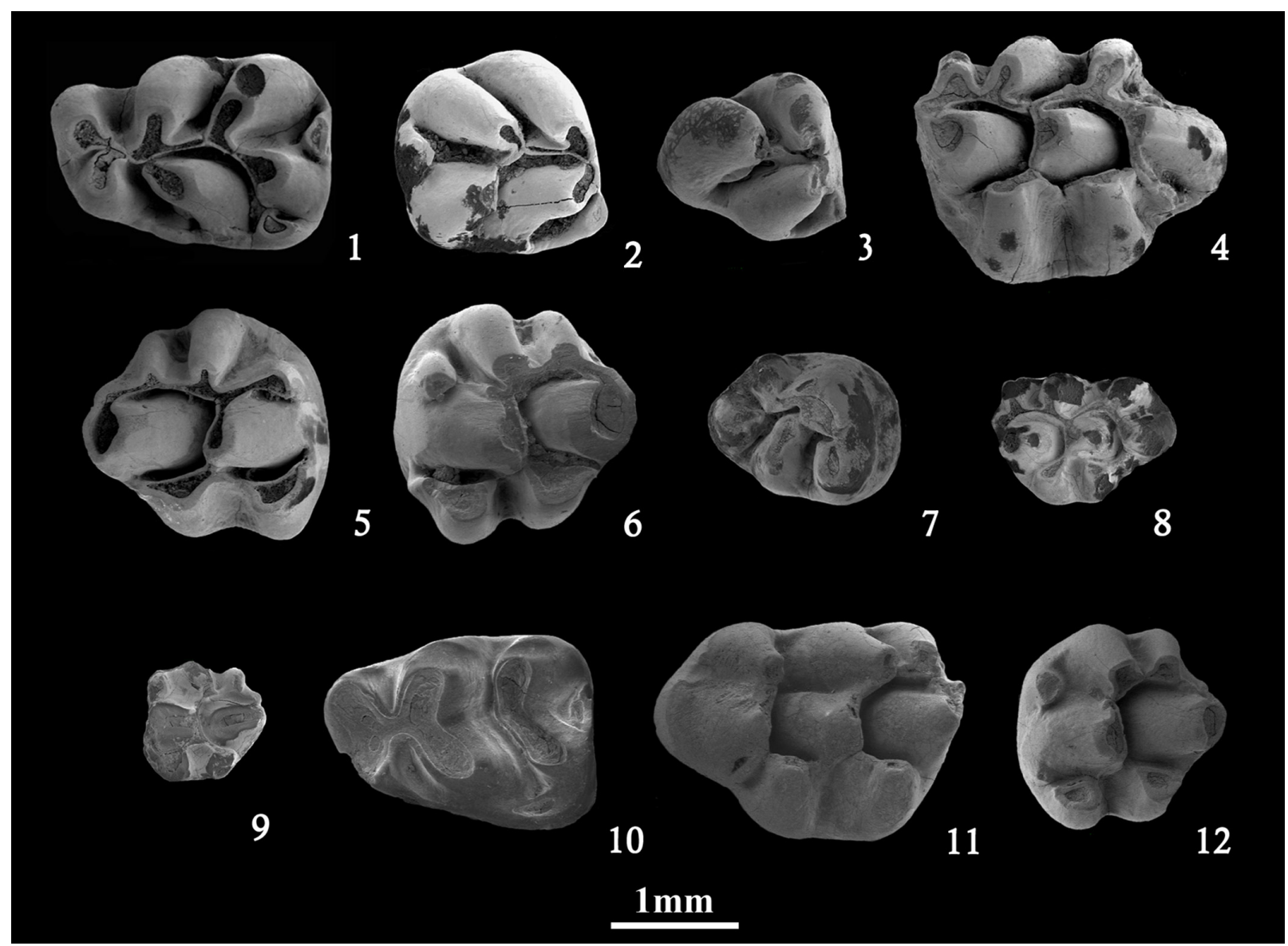

Fig. 5.- Rodent faunas from AL2D (Alcoy basin, Spain). Stephanomys cordii from AL2D. 1, left m1, AL2D-7; 2, right m2, AL2D-55; 3, right m3, AL2D-73; 4, right M1, AL2D-98; 5, right M2, AL2D-149; 6, left M2, AL2D-143; 7, right M3, AL2D-193. Castillomys gracilis from AL2D. 8, right M1, AL2D-138; 9, left M2, AL2D-185. Occitanomys brailloni from AL2D. 10, left m1, AL2D-16; 11, left M1, AL2D-113; 12, left M2, AL2D-173. Scale $=1 \mathrm{~mm}$.

Fig. 5.- Faunas de roedores AL2D (Alcoy basin, Spain). Stephanomys cordii de AL2D. 1, m1 izquierdo, AL2D-7; 2, m2 derecho, AL2D-55; 3, m3 derecho, AL2D-73; 4, M1 derecho, AL2D-98; 5, M2 derecho, AL2D-149; 6, M2 izquierdo, AL2D-143; 7, M3 derecho, AL2D-193. Castillomys gracilis de AL2D. 8, M1 derecho, AL2D-138; 9, M2 izquierdo, AL2D-185. Occitanomys brailloni de AL2D. 10, m1 izquierdo, AL2D-16; 11, M1 izquierdo, AL2D-113; 12, M2 izquierdo, AL2D-173. Escala=1mm.

show an accessory cusp in contact with the protoconid. One of the specimens presents a poorly developed longitudinal spur. The posterior heel is reduced and lingually displaced. Two roots.

m3: The anterolabial cusp is highly reduced or completely absent. The hypoconid-entoconid complex is separated from the anterior complex. One specimen presents a small $\mathrm{c} 1$ attached to the posterior complex.

M1: The connection between $\mathrm{t} 1$ and $\mathrm{t} 2$ is lower than the connection between $\mathrm{t} 2$ and $\mathrm{t} 3$. The $\mathrm{t} 2$ and $\mathrm{t} 3$ are very close together. One of the specimens presents a very small distal spur on the $\mathrm{t} 3$ directed towards the $\mathrm{t} 5$. There are no connections between $\mathrm{t} 1$ and $\mathrm{t} 3$ with $\mathrm{t} 5$. The connection between $\mathrm{t} 4$ and $\mathrm{t} 8$ is very low. There is a small $\mathrm{t} 12$.

M2: The $\mathrm{t} 1$ and $\mathrm{t} 3$ are isolated. The $\mathrm{t} 3$ is highly reduced. In three of the specimens a small distal spur on the posterior part of $\mathrm{t} 1$ directed towards the $\mathrm{t} 4-\mathrm{t} 5$ intersection can be observed. The connection between $t 4$ and $t 8$ is very low. The $\mathrm{t} 9$ and $\mathrm{t} 12$ are absent.
M3: Large and isolated $\mathrm{t} 1$. The $\mathrm{t} 3$ is absent. The connection between $\mathrm{t} 8$ and t4-t5-t6 is very low, and in two of the specimens completely isolated. There are three roots.

\section{Discussion:}

Paraethomys meini (Michaux, 1969) from AL2C and AL2D is much smaller than P. abaigari Adrover, Mein and Moissenet, 1988 and P. jaegeri Montenat and de Brujin, 1976. Moreover, despite being similar in size to the molars of P. belmezi Castillo, 1990, these teeth differ from our specimens by the presence of a well-developed tma in the $\mathrm{m} 1$, loss of the $\mathrm{t} 3$ and isolation of $\mathrm{t} 8$ in $\mathrm{M} 2$ and unconnected t6 and $\mathrm{t} 9$ in the M1. Two of the M2 present a distal spur on the posterior part of the $t 1$ directed towards the $\mathrm{t} 3 \mathrm{-} \mathrm{t} 5$ intersection, which is absent in the specimens from Alcoy-2 studied by Esteban Aenlle and Lacomba (1988). The measurements of the specimens from AL2C and AL2D are similar to those of P. meini from the lo- 
calities of Sète (type locality), Layna, Nîmes, La Juliana, Arquillo III, Villalba Alta, Perpignan, Aldehuela, Orrios (Adrover, 1986), Villalba Alta Río, Peralejos E (Adrover et al., 1988), and P. anomalus from Maritsa and $P$. miocaenicus from Khendek el Ouaich (Adrover, 1986), considered synonyms of $P$. meini by several authors (van de Weerd, 1976; Adrover, 1986; Castillo, 1990; Minwer-Barakat, 2005; García-Alix, 2006, García-Alix et al., 2008b). The size of our specimens is consistent with the measurements and morphology of $P$. meini from Celadas 9 and La Gloria 4 (Adrover et al., 1993), PUR-3, 4, 7 and 13, CLC-3, 3A, 4A, 4B, 5A, CAC-11, BRA-5B, DHS-1, 4A, 4B, 15B, 16 and MNA-4 (GarcíaAlix et al., 2008b).

\section{Paraethomys aff. abaigari Adrover, Mein and} Moissenet, 1988 (Fig. 3, 18-23)

\section{Localities: AL2C, AL2D}

Material: $14 \mathrm{~m} 1$ (AL2C-4 to AL2C-6, AL2C-8, AL2C86, AL2D-1, AL2D-2, AL2D-28 to AL2D-30, AL2D34, AL2D-36, AL2D-38, AL2D'08-2), 10 m2 (AL2C-9, AL2C-13, AL2C-14, AL2C-19, AL2C-44, AL2D-47, AL2D-48, AL2D-61, AL2D-349, AL2D-354), $5 \mathrm{~m} 3$

\begin{tabular}{|c|c|c|c|c|c|c|}
\hline Element & Locality & Parameter & $\mathrm{n}$ & $\min$. & mean & Max. \\
\hline \multirow[t]{4}{*}{$\mathrm{m} 1$} & AL2D & $\mathrm{L}$ & 3 & 23.40 & 24.20 & 25.30 \\
\hline & & W & 6 & 14.00 & 14.60 & 15.40 \\
\hline & AL2C & $\mathrm{L}$ & 1 & - & 23.30 & - \\
\hline & & W & 3 & 13.90 & 14.90 & 16.00 \\
\hline \multirow[t]{4}{*}{$\mathrm{m} 2$} & AL2D & $\mathrm{L}$ & 3 & 16.70 & 18.10 & 18.90 \\
\hline & & W & 3 & 15.20 & 16.10 & 17.20 \\
\hline & AL2C & $\mathrm{L}$ & 4 & 17.30 & 18.50 & 19.20 \\
\hline & & W & 5 & 14.60 & 15.80 & 16.80 \\
\hline \multirow[t]{4}{*}{$\mathrm{m} 3$} & AL2D & $\mathrm{L}$ & 3 & 15.60 & 16.00 & 16.20 \\
\hline & & W & 3 & 13.10 & 13.80 & 14.30 \\
\hline & AL2C & $\mathrm{L}$ & 1 & - & 16.20 & - \\
\hline & & W & 1 & - & 14.40 & - \\
\hline \multirow[t]{4}{*}{ M1 } & AL2D & $\mathrm{L}$ & 4 & 26.20 & 26.90 & 27.60 \\
\hline & & W & 4 & 18.00 & 18.30 & 18.70 \\
\hline & AL2C & $\mathrm{L}$ & 1 & - & 25.40 & - \\
\hline & & W & 1 & - & 18.40 & - \\
\hline \multirow[t]{4}{*}{ M2 } & AL2D & $\mathrm{L}$ & 12 & 17.60 & 19.70 & 21.60 \\
\hline & & W & 13 & 15.70 & 17.40 & 18.40 \\
\hline & AL2C & $\mathrm{L}$ & 2 & 18.30 & 19.40 & 20.60 \\
\hline & & W & 3 & 16.60 & 17.50 & 18.00 \\
\hline \multirow[t]{2}{*}{ M3 } & AL2D & L & 8 & 12.60 & 13.60 & 14.70 \\
\hline & & W & 8 & 12.80 & 13.30 & 14.70 \\
\hline
\end{tabular}

Table 5.- Measurements in tenths of a millimeter of the teeth of Paraethomys aff. abaigari from the localities AL2C and AL2D. $\mathrm{n}=$ number of measurable specimens.

Tabla 5.- Medidas en décimas de milímetro de los dientes de Paraethomys aff. abaigari de las localidades AL2C and AL2D. n= número de especímenes medibles.
(AL2C-49, AL2D-75, AL2D-76, AL2D-80, AL2D'088), 6 M1 (AL2C-54, AL2D-101, AL2D-103, AL2D-104, AL2D-110, AL2D-122), 16 M2 (AL2C-28, AL2C-36, AL2C-38, AL2D-146, AL2D-148, AL2D-150, AL2D154, AL2D-156 to AL2D-158, AL2D-160, AL2D-162, AL2D-168 to AL2D-170, AL2D-235), 9 M3 (AL2D-192, AL2D-194, AL2D-195, AL2D-197, AL2D-199, AL2D200, AL2D-203, AL2D-208, AL2D-209)

Measurements: see Table 5

\section{Description:}

$m 1$ : Slightly asymmetrical anteroconid. In worn specimens the connection between anteroconid and protoconid-metaconid pair is more evident. The labial cingulum is moderately developed. There is a large $\mathrm{c} 1$ in contact with the protoconid and an accessory cusp adjacent to the hypoconid. Some specimens have a small longitudinal spur. The posterior heel is small, lingually displaced and oval. Two roots.

$m 2$ : The anterolabial cusp is big, isolated from the other cusps but in contact with the labial cingulum. A small $\mathrm{c} 1$ can be observed in five of the specimens. The posterior heel is small, laminar or oval-shaped and lingually displaced.

$m 3$ : Both the anterolabial cusp and the $\mathrm{c} 1$ are absent. The hypoconid-entoconid complex is separated from the anterior complex. Two roots.

M1: The connection between $\mathrm{t} 1$ and $\mathrm{t} 2$ is very low. The $\mathrm{t} 2$ and $\mathrm{t} 3$ are very close together. Distal spurs from the $\mathrm{t} 1$ and $\mathrm{t} 3$ towards the $\mathrm{t} 4 \mathrm{-t} 5$ and $\mathrm{t} 5$ - $\mathrm{t} 6$ connections respectively may be present. There is a small t12. There are three roots.

M2: The $\mathrm{t} 1$ and $\mathrm{t} 3$ are isolated. The $\mathrm{t} 3 \mathrm{is}$ reduced. Some specimens have a distal spur directed towards the t4-t5 intersection. The $\mathrm{t} 9$ is absent. The connection between $\mathrm{t} 4$ and $t 8$ is very low. The outline of some of the specimens, the best preserved ones, seems more elongated than the others, and much more than $P$. meini.

M3: The $\mathrm{t} 1$ is large and isolated. The $\mathrm{t} 3 \mathrm{is}$ absent. The connection between $\mathrm{t} 8$ and t4-t5-t6 is very low, and in some specimens this cusp is almost isolated. Three roots.

\section{Discussion:}

The Paraethomys from AL2C and AL2D can be grouped in two clusters in terms of size. The smaller specimens can be assigned to Paraethomys meini, while the larger ones show many of the features of $P$. abaigari from Villalba Alta Río (type locality), such as a reduced longitudinal spur in $\mathrm{m} 1$, moderate labial cingulum, large c1 and moderate posterior heel (Adrover et al., 1988; García-Alix et al., 2008b). Also, these molars differ from 


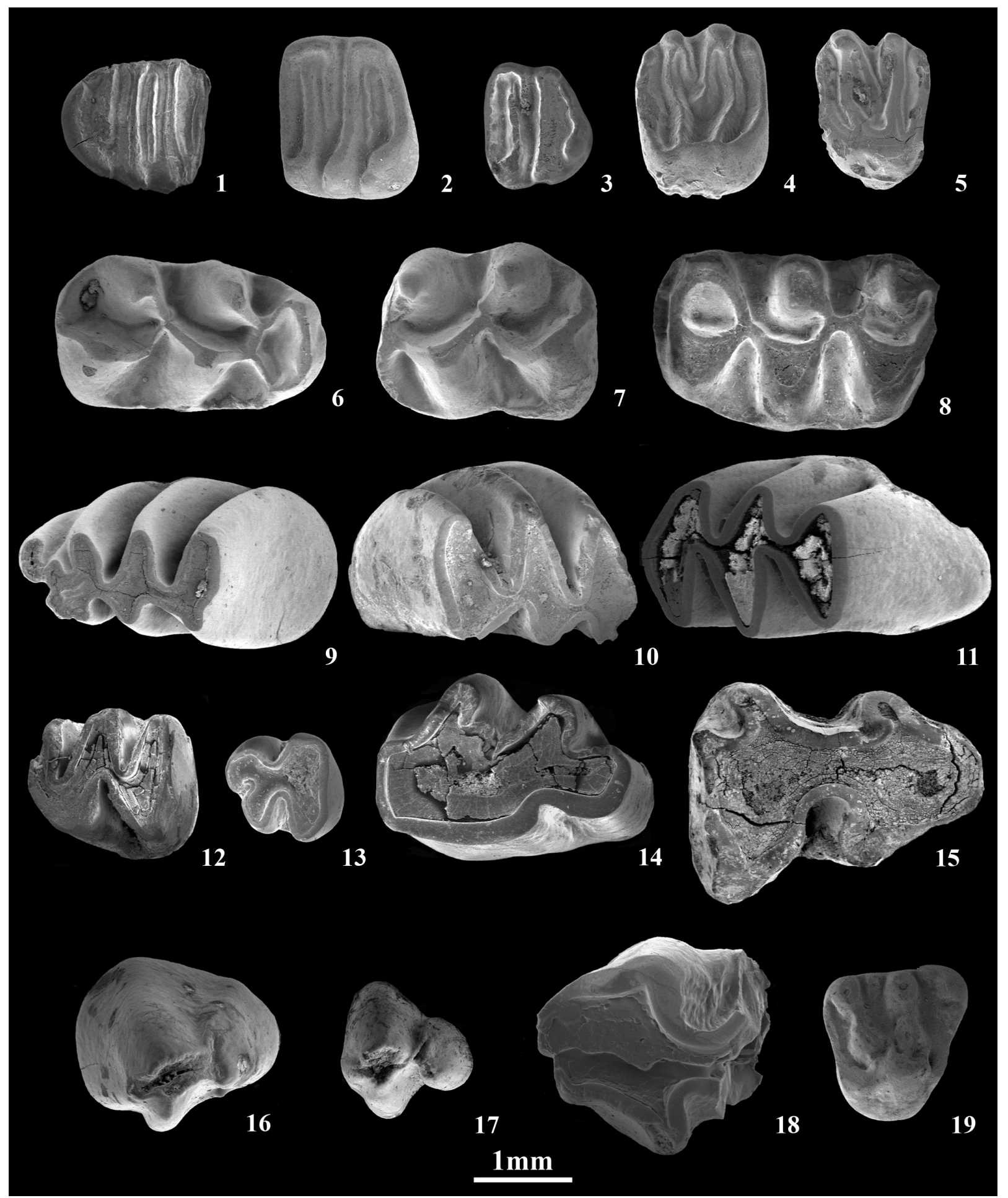

Fig. 6.- Rodent faunas from AL2C and AL2D (Alcoy basin, Spain). Glis sp. from AL2D. 1, left m3, AL2D-359. Eliomys intermedius from AL2D. 2, left m1-m2, AL2D-290; 3, left m3, AL2D-356; 4, right M1-M2, AL2D-291; 5, left M1-M2, AL2D-293. Apocricetus cf. angustidens from AL2D. 6, right m1, AL2D-260; 7, left m2, AL2D-262; 8, left M1, AL2D-259. Trilophomys cf. castroi from AL2C and AL2D. 9, left m1, AL2D300; 10, right m2, AL2D-301; 11, left M1, AL2D'08-14; 12, right M2, AL2C-83; 13, right M3, AL2D-316; Ruscinomys cf. lasallei from AL2C and AL2D. 14, left m3, AL2C-69; 15, left M2, AL2D-317; 16, left M3, AL2D-306; 17, left M3, AL2D-281; Blancomys aff. sanzi from AL2D. 18, left m1, AL2D-318. Pliopetaurista sp. from AL2D. 19, right D4, AL2D-295. Scale=1mm.

Fig. 6.- Faunas de roedores de AL2C y AL2D (Cuenca de Alcoy, España). Glis sp. de AL2D. 1, m3 izquierdo, AL2D-359. Eliomys intermedius de AL2D. 2, m1-m2 izquierdo, AL2D-290; 3, m3 izquierdo, AL2D-356; 4, M1-M2 derecho, AL2D-291; 5, M1-M2 izquierdo, AL2D-293. Apocricetus cf. angustidens de AL2D. 6, m1 derecho, AL2D-260; 7, m2 izquierdo, AL2D-262; 8, M1 izquierdo, AL2D-259. Trilophomys cf. castroi de AL2C y AL2D. 9, m1 izquierdo, AL2D-300; 10, m2 derecho, AL2D-301; 11, M1 izquierdo, AL2D'08-14; 12, M2 derecho, AL2C83; 13, M3 derecho, AL2D-316; Ruscinomys cf. lasallei de AL2C y AL2D. 14, m3 izquierdo, AL2C-69; 15, M2 izquierdo, AL2D-317; 16, M3 izquierdo, AL2D-306; 17, M3 izquierdo, AL2D-281; Blancomys aff. sanzi de AL2D. 18, m1 izquierdo, AL2D-318. Pliopetaurista sp. de AL2D. 19, D4 derecho, AL2D-295. Escala= $1 \mathrm{~mm}$. 
P. meini in their development of distal spurs in the $\mathrm{t} 1$ and $\mathrm{t} 3$ and persistence of the $\mathrm{t} 12$ in the M1. However, our specimens are slightly smaller than $P$. abaigari from Villalba Alta Río, while very similar to those of Paraethomys aff. abaigari from CLC-5, PUR-13 (García-Alix et al., 2008b), La Gloria 4 and Celadas 9 (Adrover et al., 1993). These teeth reach some of the lower values of $P$. jaegeri, although the mean values are always bigger in the latter species. For these reasons we ascribe our material to Paraethomys aff. abaigari.

The coexistence of two Paraethomys species of different size has been recorded in a number of Pliocene localities from the Teruel basin, as Villalba Alta Río, La Judería, Celadas 6 (Adrover et al., 1988), Villalba Alta 1, La Gloria 4 (Mein et al., 1990), Celadas 14, Celadas 5, Celadas 5A and Celadas 9 (García-Alix et al., 2008b) (Fig. 4). Adrover (1986) also described a big-sized form of Paraethomys associated to P. meini in the localities of Séte and Villalba Alta, where he found P. jaegeri and $P$. aff. jaegeri respectively. The localities CLC-5A and PUR-13 from the Granada basin have yielded remains of both Paraethomys meini and Paraethomys aff. abaigari (García-Alix et al., 2008b) (Fig. 4). Also, Adrover et al. (1988) recognized individuals of a big-sized phylogenetic lineage of Paraethomys in the localities of Gorafe 1 and Gorafe-A, while in the faunal lists given by Ruiz Bustos et al. (1984) and Agustí and Martín Suárez (1984) for Gorafe-A and Gorafe 1 respectively, the only Paraethomys species mentioned are $P$. cf. meini in Gorafe 1 and P. meini in Gorafe A (Fig. 4). Montenat and de Bruijn (1976) cited two Paraethomys species in the locality of La Juliana (Murcia): the big-sized P. jaegeri and the smaller P. meini. García-Alix (2006) noted that, when two species of Paraethomys coexist, like in the Ruscinian localities of PUR-13 and CLC-5A, the size of P. meini is quite reduced, which agrees with $P$. meini from AL2C and AL2D, whereas in older localities like PUR-4 the two lineages cannot be distinguished. This author found the same situation in several Lower Pliocene localities of the Teruel basin, like Celadas 5, 5A, 9 and 14, and La Gloria 4, where $P$. meini appears associated with $P$. aff abaigari, and in younger localities like Celadas 6, La Judería and Villalba Alta Río 1 (Adrover et al., 1988; Mein et al., 1990), where the big-sized Paraethomys is identified as P. abaigari. In the material from Alcoy-2, Esteban Aenlle and Lacomba (1988) distinguished two Paraethomys species, P. jaegeri and P. meini (Table 3). In our revision of the material, we observed that the Paraethomys from this locality formed two clusters in terms of size that are almost coincident with the size ranges of the Paraethomys in our collections. Therefore, we consider P. jaegeri from the Alcoy-2 collection housed at the Universidad Complutense de Madrid (UCM) to be
P. aff. abaigari. Mein et al. (1990) noted that the sizes of both lineages of Paraethomys tend to increase over time, setting the succession $P$. aff. abaigari $-P$. abaigari - P.aff. jaegeri - P. jaegeri for the linage of larger size. Nevertheless, the relationship between the two forms is not clear, being uncertain wether $P$. abaigari descends from $P$. meini or is an immigrant taxon (García-Alix et al., 2008b).

Genus: Stephanomys Schaub, 1938

Stephanomys cordii Ruiz Bustos, 1986 (Fig. 5, 1-7)

Localities: AL2C, AL2D

Material: $26 \mathrm{~m} 1$ (AL2C-2, AL2C-7, AL2D-3 to AL2D14, AL2D-18 to AL2D-20, AL2D-27, AL2D-31 to AL2D-33, AL2D-35, AL2D-37, AL2D-39, AL2D-139, AL2D'08-1) $23 \mathrm{~m} 2$ (AL2C-10, AL2C-15 to AL2C-18, AL2D-43, AL2D-44, AL2D-46, AL2D-49, AL2D-52 to AL2D-55, AL2D-57, AL2D-59, AL2D-60, AL2D-63, AL2D-186 to AL2D-189, AL2D-231, AL2D-353), $20 \mathrm{~m} 3$ (AL2C-52, AL2C-59, AL2C-60, AL2D-73, AL2D-77 to AL2D-79, AL2D-81, AL2D-82, AL2D-84 to AL2D-86, AL2D-89, AL2D-94, AL2D-95, AL2D-224, AL2D-236,

\begin{tabular}{|c|c|c|c|c|c|c|}
\hline Element & Locality & Parameter & $\mathrm{n}$ & $\min$. & mean & Max. \\
\hline \multirow[t]{4}{*}{$\mathrm{m} 1$} & AL2D & $\mathrm{L}$ & 17 & 21.20 & 22.40 & 23.80 \\
\hline & & W & 21 & 12.90 & 14.40 & 15.50 \\
\hline & AL2C & $\mathrm{L}$ & 2 & 22.20 & 23.00 & 23.80 \\
\hline & & W & 1 & - & 15.10 & - \\
\hline \multirow[t]{4}{*}{$\mathrm{m} 2$} & AL2D & $\mathrm{L}$ & 16 & 15.50 & 16.50 & 18.30 \\
\hline & & W & 16 & 14.30 & 15.90 & 17.20 \\
\hline & AL2C & $\mathrm{L}$ & 4 & 16.00 & 16.70 & 17.30 \\
\hline & & W & 5 & 14.10 & 14.80 & 16.40 \\
\hline \multirow[t]{4}{*}{$\mathrm{m} 3$} & AL2D & $\mathrm{L}$ & 16 & 12.60 & 14.20 & 15.50 \\
\hline & & W & 17 & 12.20 & 12.80 & 13.80 \\
\hline & AL2C & $\mathrm{L}$ & 3 & 12.60 & 13.10 & 13.60 \\
\hline & & W & 3 & 12.40 & 12.90 & 13.30 \\
\hline \multirow[t]{4}{*}{ M1 } & AL2D & $\mathrm{L}$ & 15 & 24.00 & 26.60 & 30.10 \\
\hline & & W & 20 & 17.10 & 18.80 & 20.20 \\
\hline & AL2C & $\mathrm{L}$ & 2 & 24.10 & 24.20 & 24.30 \\
\hline & & W & 5 & 17.20 & 18.10 & 19.30 \\
\hline \multirow[t]{4}{*}{ M2 } & AL2D & $\mathrm{L}$ & 15 & 16.30 & 18.50 & 20.40 \\
\hline & & W & 14 & 16.50 & 17.40 & 18.40 \\
\hline & AL2C & $\mathrm{L}$ & 6 & 15.20 & 16.70 & 17.70 \\
\hline & & W & 7 & 14.80 & 16.40 & 19.10 \\
\hline \multirow[t]{2}{*}{ M3 } & AL2D & $\mathrm{L}$ & 10 & 12.10 & 13.10 & 15.00 \\
\hline & & $\mathrm{W}$ & 10 & 10.70 & 11.90 & 12.60 \\
\hline
\end{tabular}

Table 6.- Measurements in tenths of a millimeter of the teeth of Stephanomys cordii from the localities AL2C and AL2D. $n=$ number of measurable specimens.

Tabla 6.- Medidas en décimas de milímetro de los dientes de Stephanomys cordii de las localidades AL2C and AL2D. n= número de especímenes medibles. 
AL2D-357, AL2D-358, AL2D'08-7), 29 M1 (AL2C-23 to AL2C-27, AL2C-56, AL2C-57, AL2D-98, AL2D-100, AL2D-102, AL2D-105 to AL2D-109, AL2D-111, AL2D112, AL2D-115 to AL2D-121, AL2D-125, AL2D-127 to AL2D-129, AL2D-234), 27 M2 (AL2C-29, AL2C-31 to AL2C-35, AL2C-39, AL2D-143 to AL2D-145, AL2D147, AL2D-149, AL2D-151 to AL2D-153, AL2D-155, AL2D-159, AL2D-161, AL2D-163, AL2D-164, AL2D166, AL2D-167, AL2D-171, AL2D, 174, AL2D-175, AL2D-180, AL2D'08-10), 10 M3 (AL2D-74, AL2D-193, AL2D-196, AL2D-198, AL2D-201, AL2D-202, AL2D204, AL2D-205, AL2D-207, AL2D-211, AL2D-221)

Measurements: see Table 6

\section{Description:}

$m 1$ : The slightly asymmetrical anteroconid is in contact with the protoconid-metaconid pair. The labial cingulum is low and narrow. There is a well-developed longitudinal crest that connects the posterior cusps with the intersection of the protoconid-metaconid pair. The $\mathrm{c} 1$ is well developed, and two of the teeth present an accessory cusp between the labial lobe of the anteroconid and the protoconid, big and round in one case and laminar and slightly smaller in the other one. The posterior heel is smaller than the $\mathrm{c} 1$, lingually displaced, and its shape may vary from round to almost laminar. The teeth have two roots.

$m 2$ : The anterolabial cusp is high, medium or big sized, and in contact with the protoconid and the reduced labial cingulum. The longitudinal crest is lingually displaced towards the metaconid. A small round or oval $\mathrm{c} 1$ is present, and a reduced accessory cusp in contact with the protoconid may also exist. The posterior heel is large, rounded or oval. There are two roots.

$m 3$ : Reduced anterolabial cusp, connected to the protoconid. The longitudinal crest seems incomplete in some specimens, being made instead by two contacting spurs. In the junction point, the enamel of each of the spurs may be differentiated from the other one. There are two roots.

M1: The $\mathrm{t} 1$ is displaced backwards. There are usually $\mathrm{t} 1$ bis and $\mathrm{t} 2$ bis, with different stages of development, although in some specimens are reduced to just a fold of enamel. The posterior crests of $\mathrm{t} 1$ and $\mathrm{t} 3$ are well developed. The $\mathrm{t} 7$ is absent. The $\mathrm{t} 12$ is highly reduced, just as a thickening of the enamel in some specimens. There are three roots.

M2: There may be a small accessory cusp attached to the posterior side of $t 1$. The posterior crests of $t 1$ and $t 3$ are usually well developed, although two specimens have the $\mathrm{t} 1$ and the $\mathrm{t} 3$ isolated respectively (Fig. 5, 6). The $\mathrm{t} 12$ is absent or reduced to a thickening of the $\mathrm{t} 8 \mathrm{-t} 9$ crest.

M3: The $\mathrm{t} 1$ is connected with $\mathrm{t} 5$. $\mathrm{T} 4$, t5 and $\mathrm{t} 6$ are connected. The $\mathrm{t} 3$ is absent except in one specimen.

\section{Discussion:}

The great height of the crown, high longitudinal crests in the lower molars (Fig. 5, 1-3) and crests or spurs in $\mathrm{t} 1$ and $\mathrm{t} 3$ of the upper molars (Figs. 5, 4-5) suggest that these specimens belong to the genus Stephanomys. These molars are smaller than other Stephanomys from the Pliocene such as $S$. donnezani (Déperet, 1890), S. balcellsi Gmelig Meyling and Michaux, 1973, S. vandeweerdi Adrover, 1986, and S. thaleri López-Martínez, Michaux and Hutterer, 1998. Although similar in size, the Stephanomys from AL2C and AL2D differ from $S$. minor Gmelig-Meyling and Michaux, 1983 in the tubercular shape of the posterior heel. The Stephanomys from AL2C and AL2D are bigger and with a more pronounced stephanodonty than S. ramblensis van de Weerd, 1976, and $S$. dubari Aguilar, Michaux, Bachelet, Calvet and Faillat, 1991. The measurements of these molars match those of S. margaritae Adrover, 1986, which are quite close in size to S. medius Cordy, 1976, from Alcoy. The specimens from AL2C and AL2D show the features used by Cordy (1976) to describe the species $S$. medius: symmetric disposition of $\mathrm{t} 1$ and $\mathrm{t} 3$ respect the $\mathrm{t} 2$ in the M1 (Fig. 5, 4), reduced labial cingulum in $\mathrm{m} 1$ and $\mathrm{m} 2$ (Fig. 5, 1-2), tubercular posterior heel (Fig. 5, 1-2) and m3 with a poorly-developed anterolabial cusp and longitudinal crest united to the protoconid (Fig. 5, 3).

According to López Martínez et al. (1998), S. medius is a nomen nudum, being the correct name of the species $S$. donnezani cordii Ruiz Bustos, 1986. This is reviewed by García-Alix et al. (2008b), elevating S. donnezani cordii to species level and renaming it as Stephanomys cordii. The size range of our specimens encloses most of the variability of $S$. margaritae and $S$. cordii, except for the maxima for $S$. margaritae and some of the minima for $S$. cordii. In this latter species, the smallest specimens are those from La Gloria 4 (Adrover et al., 1993), and Peralejos E (Adrover et al., 1988), considered to be $S$. dubari by García-Alix et al. (2008b).

Minwer-Barakat (2005) proposed an evolutionary frame for the genus Stephanomys in which there is a continued increase in size, crown height and stephanodonty during the Pliocene in the anagenetic line S. ramblensis - S. dubari - S. cordii - S. margaritae. The populations from AL2C and AL2D seem to be close to $S$. margaritae, with some specimens reaching its size or even surpassing it, like one exceptionally large M1, while the mean values are more consistent with $S$. cordii. Those specimens have been directly compared with the collection from Alcoy-2, kept at the Universidad Complutense de Madrid (UCM), and ascribed by Esteban Aenlle and Lacomba (1988) to S. medius (Table 3). Both their size and morphology are very similar to our specimens. We ascribe our material 
to $S$. cordii because of its similarity with the population from the type locality, Alcoy (Cordy, 1976).

Genus Castillomys Michaux, 1969 (Fig. 5, 8-9)

Castillomys gracilis van de Weerd, 1976

Locality: AL2D

Material: 2 M1 (AL2D-138, AL2D-233), 1 M2

(AL2D-185)

\section{Description:}

M1: (15.80 x 11.20): The $\mathrm{t} 1$ is situated much posterior than the $\mathrm{t} 2$. The $\mathrm{t} 1$ has a hint of longitudinal spur directed towards the t4-t5 intersection. The $\mathrm{t} 3$ has a distal spur directed towards the $\mathrm{t} 5-\mathrm{t} 6$ intersection. The $\mathrm{t} 3$ is far apart from t6. The $\mathrm{t} 9$ is elongated. A small t12 is present. In lateral view, t6 is quite straight, not directed towards $t 9$. This character has been used to distinguish the genus Castillomys from the small forms of Occitanomys (Martín-Suárez and Mein, 1991).

M2: (10.50 x 09.50): Tooth in an advanced stage of wear. The lingual longitudinal crest connects $\mathrm{t} 1$ and $\mathrm{t} 5$. Isolated $\mathrm{t} 3$. The $\mathrm{t} 6$ and $\mathrm{t} 9$ are equivalent in size. The $\mathrm{t} 12$ is small but well formed.

\section{Discussion:}

The small size of these specimens, straight t6 in lateral view, absence of a 77 in the upper molars and presence of posterior spurs in the $\mathrm{t} 1$ and $\mathrm{t} 3$ of the $\mathrm{M} 1$ are typical of the genus Castillomys. Also, the lack of longitudinal crests in the upper molars and isolated $\mathrm{t} 3$ in M2 (Fig. 5, 8) agree with Castillomys gracilis van de Weerd, 1976. The size of the specimens recovered from AL2C and AL2D lies within the range of variation of $C$. gracilis from Caravaca, Orrios 1 (van de Weerd, 1976), MontHélène (Aguilar et al. 1986), Aldehuela and Villalba Alta (Adrover, 1986), Moreda 1A and Moreda 1B (Castillo, 1990), CLC-3, CLC-3B and PUR-13 (García-Alix et al., $2008 \mathrm{~b}$ ), although the width of the single M2 recovered from AL2D, in a very poor state of preservation, is only comparable to the lower values of the specimens from Caravaca (van de Weerd, 1976). Their size is also consistent with C. gracilis from the collection of Alcoy-2 at the Universidad Complutense de Madrid (UCM).

Martín-Suárez and Mein (1991) propose an evolutionary scenario in which all the Iberian populations from the Pliocene and Pleistocene could be placed in an anagenetic lineage consisting of three consecutive taxa: $C$. gracilis - C. crusafonti - C. rivas. These authors recognized an increase in size through time, such that the biomet- rics of the molars can be used as systematic criteria. In the line $C$. gracilis - C. crusafonti, only the development of $\mathrm{t} 1 \mathrm{bis}$ and the lingual longitudinal crest (t1-t5) show a positive correlation, whereas the states of the remaining characters are independent from other characters and size. This results in a differential diagnosis for the various species of Castillomys based on frequency percentages of the different characters along with size (Martín-Suárez and Mein, 1991). The oldest representative of the genus, C. margaritae Antunes and Mein, 1989, differs from our material by the absence of $\mathrm{t} 12$.

Genus: Occitanomys Michaux, 1969

Occitanomys brailloni Michaux, 1969 (Fig. 5, 10-12)

Locality: AL2D

Material: $1 \mathrm{~m} 1$ (AL2D-16), 3 M1 (AL2D-99, AL2D113, AL2D-114), 1 M2 (AL2D-173)

\section{Description:}

$m 1$ : $(21.30 \times 15.80)$ : Very worn specimen. Slightly asymmetrical anteroconid. The anteroconid and the protoconid-metaconid are connected by a narrow crest. The labial cingulum is very wide and well developed, but no accessory cusps are observed. The c1 is large and elongated anteroposteriorly, which gives this cusp a comma shape. There is no longitudinal spur. Oval posterior heel.

M1: $(25.60 \times 18.00 ; 25.40 \times 18.1 ; 25.70 \times 17.70)$ : The connection between $\mathrm{t} 1$ and $\mathrm{t} 2$ is very basal. There is a well developed $\mathrm{t} 1 \mathrm{bis}$ in all specimens, and a smaller $\mathrm{t} 2$ bis is present in one of the teeth. The $t 1$ has a distal spur directed to the $\mathrm{t} 4-\mathrm{t} 5$ intersection, but the $\mathrm{t} 3$ has no distal spur. The t12 is very small. In labial lateral view, these teeth show that the t6 leans towards the $\mathrm{t} 9$, and the apex of the cusp is closer to t 9 than to $\mathrm{t} 3$.

M2: $(15.80 \times 15.70)$ : The $t 1$ is much bigger than $t 3$, and connected basally to $t 5$, while $t 3$ is isolated. The shape of $\mathrm{t} 1$ suggests the presence of a small $\mathrm{t} 1$ bis. The $\mathrm{t} 9$ is well developed. The 112 is very small, barely a fold of the enamel.

\section{Discussion:}

The material from AL2D belongs to a big-sized form of Occitanomys. The outline and general morphology of the specimens is consistent with $O$. brailloni Michaux, 1969, having an $\mathrm{m} 1$ without tma and a labial cingulum with accessory cusps less developed than Apodemus, a $\mathrm{t} 1$ bis always present in the $\mathrm{M} 1$, reduced $\mathrm{t} 12$, reduced $\mathrm{t} 3$ and $\mathrm{t} 1$ connected to $\mathrm{t} 5$ in M2 (Michaux, 1969) (Fig. 5, 10-12). According to Minwer-Barakat (2005), this taxon 
is more frequent during the late Ruscinian, although it can be found in some early Ruscinian localities such as Aldehuela (Adrover, 1986), Ptolemais 1 and Kardia (van de Weerd, 1979).

The single $\mathrm{m} 1$ recovered is consistent with the the greatest lengths of $O$. brailloni from the locality of Layna (Michaux, 1969), and close to the maxima from Nîmes (Michaux, 1969), Arquillo 3 (Adrover, 1986), and TCH1B (Minwer-Barakat et al., 2005). The width of this molar, however, clearly surpasses the maxima of the populations from the cited sites. The M1 are bigger than $O$. brailloni from Séte, Nîmes and Layna (Michaux, 1969), Arquillo 3 and Aldehuela (Adrover, 1986) and TCH-1B (Minwer-Barakat et al., 2005). The size of the single M2 lies within the variation observed in the material from Villalba Alta (Adrover, 1986). The site of AL2C has not yielded any remains of $O$. brailloni. This may be due to the scarcity of the material of this taxon, usually scarce in the localities where it is found. In the faunal list published by Esteban Aenlle and Lacomba (1988) for Alcoy-2, these authors did not mention any form of Occitanomys (Table 3 ). However, a revision of the material from this locality has shown a few specimens, morphologically very similar to the molars described in this paper, and which in our opinion correspond to a big sized Occitanomys.

Family: Gliridae Muirhead, 1819

Subfamily: Dryomyinae de Bruijn, 1967

Genus: Eliomys Wagner, 1840

Eliomys intermedius Friant, 1953 (Fig. 6, 2-5)

Localities: AL2C, AL2D

Material: 2 m1,2 (AL2C-97, AL2D-290), 2 m3 (AL2C47, AL2D-356), 3 M1,2 (AL2D-291 to AL2D-293)

\section{Description:}

$m 1,2:(15.60 \times 17.10 ;-\times 16.10)$ : The anterolophid is continuous and connected to the protoconid. There is no anterotropid. The connection between metalophid and metaconid is very low. The centrolophid is long and not connected to the metalophid. Metaconid and entoconid separated by a deep valley. The mesolophid is connected to the entoconid. The mesoconid is situated on the labial border. Well-developed posterotropid. The hypoconid is very large.

$m 3:(13.90 \times 14.80)$ : Continuous anterolophid, in contact with the metaconid. The labial apex of the metalophid does not reach the metaconid. The accessory crests are absent. The centrolophid is shorter than in $\mathrm{m} 1,2$. There is a wide valley between metaconid and entoconid. Continuous posterolophid.
M1,2: $(13.80 \times 17.40 ; 15.80 \times 19.50)$ : The anteroloph is separated from both the protoloph and the paracone by a deep valley. There are neither anterotrope nor posterotrope. Paracone and metacone are high and separated. The protoloph and metaloph are continuous. In the only complete specimen, there are two centrolophs. Well developed precentroloph, much longer than the postcentroloph. The endoloph and posteroloph are connected and continuous.

\section{Discussion:}

The size of our specimens, the rounded outline, the height of the crests and the development of the centrolophs make us assign those teeth to E. intermedius. The measurements of the molars from AL2C and AL2D fall within the range of variation of the population from the type locality, Sète (Adrover, 1986), and are very similar to those of E. intermedius from Orrios 3 and Eliomys cf. intermedius from Arquillo 3, Villalba Alta (Adrover, 1986) and Mont Hélène (Aguilar et al., 1986). Their size is bigger than E. truci, Mein and Michaux, 1970, and slightly bigger than $E$. aff. intermedius from La Gloria 4, La Gloria 5 (Adrover et al., 1993), PUR-4 and CLC3B (García-Alix et al., 2008a), falling within the ranges of variation of E. intermedius from TCH-3, TCH-1B and PUR-13 (García Alix et al., 2008a). Both morphology and size in AL2C y AL2D are very similar to the specimens from Alcoy-2 deposited at the Universidad Complutense de Madrid (UCM), which lack in the preliminary faunal list published by Esteban Aenlle and Lacomba (1988) (Table 3).

Subfamily: Glirinae Thomas, 1897

Genus: Glis Brisson, 1762

Glis sp. (Fig. 6, 1)

Locality: AL2D

Material: $1 \mathrm{~m} 3$ (AL2D-359)

\section{Description:}

m3: (15.29 x 14.09): Tooth with four main ridges (anterolophid, metalophid, mesolophid and posterolophid) and three well-developed extra ridges (anterotropid, extra ridge between metalophid and mesolophid and posterotropid). Every ridge, except for the posterolophid, is clearly transverse. Very long anterotropid, connected to the metaconid. The extra ridge between metalophid and mesolophid is very long, of the same length as the anterotropid and not connected to the metalophid or the mesolophid. Mesolophid and posterolophid are not connected to the lingual border. Long posterotropid, connected to the 
lingual end of the posterolophid. The posterolophid is partially interrupted at the postero-lingual corner of the tooth.

\section{Discussion:}

The presence of several transverse main and extra ridges allow to assign this material to a form of the genus Glis. At the labial border, the main ridges (anterolophid, metalophid, mesolophid and posterolophid) are not connected, and define synclines that are opened on the labial side.

In the Pliocene two species of the genus Glis have been described: Glis minor Kowalski, 1956 and Glis sackdillingensis Heller, 1930 (Kowalski, 1956; Aguilar et al., 1986), whereas in the Pleistocene several species of the genus have been cited: G. sackdillingensis, G. mihevci Aguilar and Michaux, 2011, G. perkoi Aguilar and Michaux, 2011 and the extant G. glis (Linnaeus, 1766) (Kowalski, 1963; Aguilar and Michaux, 2011). A gradual size increase of the molars is observed in Glis between the Pliocene and today. Morphology has evolved in this time span from primitive forms with transversal crests, synclines open on the lingual side in the upper molars and labial side in lower ones and accessory ridges reduced in p4 and m3 (Kowalski, 1956; Aguilar and Michaux, 2011).

The $\mathrm{m} 3$ from AL2D shows measurements and some of the morphological features that characterize the primitive assemblages of the genus Glis. The size is intermediate between G. minor and G. mihevci-G. perkoi-G. glis, and maybe more similar to G. sackdillingensis. The presence of transversal crests and open synclines on the labial side of the $\mathrm{m} 3$ are typical of the primitive forms. Nevertheless, the well-developed anterotropid and posterotropid are different from the Pliocene assemblages of the genus. These extra ridges are very long, exceeding extensively the middle of the tooth, and are connected to the metaconid and the lingual end of the posterolophid, respectively. The size and morphology of these ridges is similar to the Pleistocene species of the genus (G. mihevci-G. perkoi-G. glis) and different from the Pliocene species (G. minor-G. sackdillingensis). Castillo (1990) cites G. sackdillingensis in Alcoy-2, although in the original list published by Esteban Aenlle and Lacomba (1988) the genus Glis is not mentioned. Based on these features and until more material becomes available, we consider the specimen from AL2D as belonging to Glis sp.

Family: Cricetidae Fischer, 1817

Subfamily: Cricetinae Fischer, 1817

Genus: Apocricetus Freudenthal, Mein and MartínSuárez, 1998

Apocricetus cf. angustidens (Depéret, 1890) (Fig. 6, 6-8)

Localities: AL2C, AL2D
Material: $1 \mathrm{~m} 1$ (AL2D-260), $1 \mathrm{~m} 2$ (AL2D-262), 2 m3 (AL2D-264, AL2D-266), 1 M1 (AL2D-259), 3 M2 (AL2C-93, AL2D-65, AL2D-263)

\section{Description:}

$m 1$ : $(27.20 \times 15.80)$ : Smooth, crest-like anteroconid. There are two anterolophulids, well developed and symmetrical, reaching the top of the anterolophid crest, encircling an anterior funnel. The metalophulid is strongly directed forwards. Absent mesolophid. The posterolophid is high and connected to the entoconid, closing the posterosinusid.

$m 2:(22.60 \times 17.90)$ : The lingual anterolophid and the mesolophid are absent. The labial anterolophid is low, reaching the protoconid.

$m 3:(22.10 \mathrm{x}-;-\mathrm{x} 15.90)$ : The lingual anterolophid is absent. Mesolophid very short and low in one specimen, and absent in the other one.

M1: $(28.20 \times 18.00)$ : There is a cingulum ridge in front of an anterocone formed by two cusps in labial and lingual position. The anterolophule is double and symmetrical. Absent anterior protolophule and posterior metalophule. Absent mesoloph. The anterior metalophule is present.

M2: (21.98 x 17.77; $20.50 \mathrm{x}-$; - x 18.10): The lingual anteroloph is short and low. Absent anterior protolophule. Posterior protolophule and anterior metalophule present. The mesoloph is absent.

\section{Discussion:}

In the locality AL2D, a set of cricetid teeth, characterized by the absence of mesolophid in the $\mathrm{m} 1$ and of the anterior protolophule in M1 and M2, together with the presence of a crest-like anteroconid and a double anterolophulid in $\mathrm{m} 1$ resembles Apocricetus. In general, the size of this assemblage overlaps with the minimum values of $A$. angustidens and the maximum of $A$. barrierei (Freudenthal et al., 1998). Only the values of $\mathrm{m} 1$ from AL2D clearly exceed those of $A$. barrierei (Freudenthal et al., 1998). Although the presence of a cingulum ridge in front of the anterocone and the absence of an anterior protolophule in M1-M2 are morphological features that appear in assemblages of $A$. angustidens and $A$. barrierei, they are more common in the former ones (Freudenthal et al., 1998). Based on these features and until more material become available, we consider the assemblage from AL2D as belonging to a form related with $A$. angustidens.

A M2 (AL2C-93) from AL2C shows a poor development of the anterior protolophule and absence of the posterior metalophule, resembling the general morphology of the younger species of the genus Apocricetus (Freudenthal et al., 1998). Nevertheless, a single tooth is not 
enough to know the variability of this assemblage and, until more material becomes available, we consider it as belonging to a form related with $A$. angustidens too.

\section{Cricetidae Incertae Sedis}

Genus: Blancomys van de Weerd, Adrover, Mein \& Soria, 1977

Blancomys sp. (Fig. 6, 18)

Locality: AL2D

Material: $1 \mathrm{~m} 1$ (AL2D-318)

\section{Description:}

$m 1$ : Tooth broken posteriorly and in an advanced stage of wear. The great lingual fold is very deep, reaching the base of the crown. The fold between anteroconid and metaconid is open and smooth, in contrast with the labial anterior fold, which is very sharp. Nevertheless, both folds reach the base of the crown. The metaconid is well developed, much more than the anteroconid and anterolophid. The anterior labial fold is very smooth, forming a straight line of enamel that connects anterolophid and protoconid. The labial fold is big, reaching the base of the crown and creating an acute vertex of enamel.

\section{Discussion:}

Esteban Aenlle and Lacomba (1988) cited the presence of Blancomys neglectus van de Weerd, Adrover and Soria, 1977, in Alcoy-2 (Table 3). The morphology, size and hypsodonty of the only tooth recovered in AL2D are consistent with Blancomys, but the scarcity of the material impedes a specific adscription.

\begin{tabular}{ccccccc} 
Element & Locality & Parameter & $\mathrm{n}$ & min. & mean & Max. \\
\hline \multirow{2}{*}{ m3 } & \multirow{2}{*}{ AL2C } & L & 1 & - & 26.30 & - \\
& & W & 1 & - & 18.10 & - \\
M2 & \multirow{2}{*}{ AL2D } & L & 1 & - & 30.10 & - \\
& & W & 2 & 21.50 & 21.75 & 22.20 \\
M3 & \multirow{2}{*}{ AL2D } & L & 2 & 19.70 & 20.00 & 20.20 \\
& & W & 2 & 17.40 & 17.60 & 17.80 \\
& & H & 1 & - & 24.90 & - \\
& \multirow{2}{*}{ AL2C } & L & 2 & 19.00 & 20.10 & 20.30 \\
& & W & 2 & 15.20 & 15.55 & 15.90 \\
& & H & 1 & - & 24.40 & -
\end{tabular}

Table 7.- Measurements in tenths of a millimeter of the teeth of Ruscinomys cf. lasallei from the localities AL2C and AL2D. $\mathrm{n}=$ number of measurable specimens.

Tabla 7.- Medidas en décimas de milímetro de los dientes de Ruscinomys cf. lasallei de las localidades AL2C and AL2D. n= número de especímenes medibles.
Subfamily: Cricetodontinae Stehlin and Schaub, 1951 Genus: Ruscinomys Depéret, 1890

Ruscinomys cf. lasallei Adrover, 1969 (Fig. 6, 14-16)

Localities: AL2C, AL2D

Material: $1 \mathrm{~m} 1$ (AL2C-70), $2 \mathrm{~m} 3$ (AL2C-69, AL2D319), 2 M2 (AL2D-308, AL2D-317), 4 M3 (AL2C-71, AL2C-72, AL2D-306, AL2D-307)

Measurements: see Table 7

\section{Description:}

$m 1$ : The tooth is broken posteriorly, and in an advanced stage of wear. No enamel islet can be observed. Rounded anteroconid. The anterosinusid is open and wide, just a slightly fold of the enamel. The mesosenid is narrow and deep, while the labial sinusid is much wider and smoother. Both folds reach the base of the crown.

$m 3$ : The anteroconid is a fold of the enamel. There are two enamel islets. The anterosinusid is smooth and open, almost reaching the base of the crown. The metaconid is round, much smaller than the entoconid. Both cusps are separated by the mesosinusid, which is very deep and steep. The posterosinusid is much narrower, but equally deep. The posterolophid and hypoconid cannot be individualized as separated cusps because of the wear of the molar. The sinusid is very narrow and deep, reaching the base of the crown.

M2: One of the specimens is broken anteriorly, while the other one is complete. In this latter individual two shallow enamel islets can be observed. The mesosinus is deep and narrow, while the sinus is much wider. Both folds reach the base of the enamel.

M3: Bilobed teeth, with the anterior lobe bigger than the posterior one. The lobes are separated by two folds reaching the base of the crown. There are two roots.

\section{Discussion:}

The rounded anteroconid (morphotype 3 of García-Alix et al., 2008a), flat labial side of the m1, M2 more elongated than Ruscinomys schaubi Villalta and Crusafont, 1956 and narrower than $R$. europaeus Depéret, 1890, and M3 with two lobes but more reduced than $R$. schaubi agree with Ruscinomys lasallei Adrover, 1969. Also, these specimens are higher crowned than $R$. schaubi, but less hypsodont than $R$. europaeus. The two unworn M3 (Table 7) are higher than R. schaubi from Concud 3, Los Mansuetos and Los Mansuetos 2, and similar to $R$. cf. lasallei from Caravaca, while shorter than $R$. europaeus from Layna (data from van de Weerd, 1976). The size of the Ruscinomys present in AL2C and AL2D is consistent with Ruscinomys lasallei Adrover, 1969 from its 
type locality, Alcoy, falling within the range of variation of this taxon from the localities of La Gloria 4 (Adrover et al., 1993), PUR-13 and PUR-4 (García-Alix et al., 2008a), being also similar to $R$. cf. lasallei from the localities of Celadas 2, Arquillo1, Arquillo 4, La Gloria 5, Valdecebro 3, Valdecebro 6, and Villastar (Adrover et al., 1993). These molars are bigger than $R$. gilvosi Adrover et al., 1988, from Peralejos E, and smaller than $R$. bravoi Adrover and Mein, 1996, from Aljezar B, especially in width. Esteban Aenlle and Lacomba (1988) assigned the material from Alcoy-2 to Ruscinomys aff. europaeus (Table 3) based on its size and morphology. However, the material from AL2C and AL2D seems somewhat smaller and more similar to $R$. lasallei than to $R$. europaeus, even falling within the upper range of variation of $R$. schaubi Villalta and Crusafont, 1956, from Aljezar B (Adrover, 1986), Los Mansuetos, Los Mansuetos 2, Concud 2 and Concud 3 (van de Weerd, 1976), and $R$. aff. schaubi from DHS-4A, 4B and 16, and PUR-23, 24A, 25 and 25A (García-Alix et al., 2008a). For these reasons we ascribe our material to $R$. cf. lasallei.

\section{Ruscinomys sp. (Fig. 6, 17) \\ Locality: AL2D \\ Material: 1 M3 (AL2D-281) \\ Description:}

M3: (14.00 x 13.90; H: 16.00): Tooth with two lobes delimited by the sinus and mesosinus. The posterior lobe is smaller than the anterior one.

\section{Discussion:}

The specimen AL2D-281 is smaller and has a lower crown than Ruscinomys lasallei and R. schaubi. Also, the posterior lobe of the M3 is less reduced than Ruscinomys, resembling Hispanomys. The smallest representative of the genus Ruscinomys is $R$. gilvosi, described by Adrover et al. (1988) in the Ruscinian locality of Peralejos E. Unfortunately, this site has not yielded any M3. The presence of two Ruscinomys species in the same locality is rare, although Peralejos E has yielded remains of both $R$. gilvosi and $R$. cf. europaeus.

Family: Trilophomyidae Kretzoi, 1969

Genus: Trilophomys Depéret, 1892

Trilophomys cf. castroi Adrover, 1983 (Fig. 6, 9-13)

Localities: AL2C, AL2D

Material: $7 \mathrm{~m} 1$ (AL2C-79 to AL2C-82, AL2D-297, AL2D-298, AL2D-300), $4 \mathrm{~m} 2$ (AL2D-301 to AL2D304), 3 M1 (AL2D-296, AL2D’08-14, AL2D'08-15), 2 M2 (AL2C-83, AL2C-85), 2 M3 (AL2D-305, AL2D-316)

Measurements: see Table 8

\section{Description:}

m1: The lingual side of the crown has three reentrant folds, while the labial one presents two. Five specimens have a well-developed anterior fold. This fold reaches near the base of the crown in one specimen, while in another three reaches two thirds of the height of the crown and in another one just the upper third. The lingual folds are deeper than the labial ones. The outward folds have acute apices. The boundary line between enamel and dentine at the base of the crown is quite smooth, rising slightly at the height of the outward folds.

$m 2$ : Both the labial and the lingual side have two reentrant folds. The folds of the labial side are much shorter than the lingual ones. The outward folds have acute apices. The labial folds are slightly displaced forwards with respect to the lingual folds. The boundary line between the enamel and dentine at the base of the crown is almost straight and parallel to the oclusal surface of the teeth, rising slightly at the height of the outward folds. The teeth have two roots.

M1: Both the labial and the lingual side have two reentrant folds. The folds of the labial side are deeper than the lingual ones. The enamel boundary is slightly wavy.

M2: Two reentrant folds in the labial side and one in the lingual side. The folds of the labial side are deeper than the lingual ones. Very smooth enamel boundary line. There are two roots.

\begin{tabular}{ccccccc} 
Element & Locality & Parameter & $\mathrm{n}$ & min. & mean & Max. \\
\hline \multirow{2}{*}{ m1 } & AL2D & L1 & 3 & 18.20 & 18.70 & 19.00 \\
& & L2 & 3 & 24.20 & 25.80 & 27.20 \\
& & W & 3 & 12.70 & 13.80 & 15.40 \\
& \multirow{2}{*}{ AL2C } & L1 & 3 & 19.60 & 21.20 & 22.30 \\
& & L2 & 3 & 24.20 & 25.80 & 27.50 \\
m2 & & W & 3 & 13.10 & 14.50 & 15.50 \\
& & L1 & 2 & 17.40 & 18.30 & 19.30 \\
& & L2 & 3 & 22.80 & 24.50 & 27.40 \\
M1 & AL2D & W1 & 4 & 12.20 & 12.80 & 14.20 \\
& & L2 & 3 & 19.90 & 20.70 & 21.30 \\
& & W & 3 & 12.30 & 12.80 & 14.20 \\
M2 & AL2C & L1 & 1 & - & 15.00 & - \\
& & L2 & 1 & - & 16.70 & - \\
& & W & 2 & 13.70 & 14.10 & 14.60 \\
M3 & AL2D & L1 & 2 & 10.80 & 11.50 & 12.30 \\
& & L2 & 2 & 11.50 & 12.60 & 13.70 \\
& & W & 2 & 11.90 & 12.00 & 12.10
\end{tabular}

Table 8.- Measurements in tenths of a millimeter of the teeth of Trilophomys cf. castroi from the localities AL2C and AL2D. $\mathrm{n}=$ number of measurable specimens.

Tabla 8.- Medidas en décimas de milímetro de los dientes de Trilophomys cf. castroi de las localidades AL2C and AL2D. n= número de especímenes medibles. 
M3: Two lobes, the anterior one larger than the posterior one. The reentrant lingual fold is deeper than the labial one. The posterior lobe is divided by an inlet of enamel in one of the specimens, displaced to the lingual side of the tooth, while in the other one this character is absent due to the extreme wear of the tooth. The boundary line between the enamel and dentine of the base of the crown is almost straight, rising slightly at the height of the outward folds. There are two roots.

\section{Discussion:}

Morphologically, the populations of Trilophomys from AL2C and AL2D are very similar to T. castroi Adrover, 1986. The Trilophomys from Alcoy-2 housed at the Universidad Complutense de Madrid (UCM, Spain) were determined as Trilophomys cf. castroi by Esteban Aenlle and Lacomba (1988) (Table 3), and seem undistinguishable from our material. The most significant character is the smooth enamel-dentine boundary. This excludes these molars from belonging to Trilophomys pyrenaicus Déperet, 1890. The size of our specimens is somewhat smaller than T. castroi from Villalba Alta, its type locality, and Arquillo III, falling within the range of variation of $T$. cf. castroi from Aldehuela and Orrios 0 (Adrover, 1986) and Villalba Alta Río (Adrover et al., 1988).

Family: Sciuridae Fisher, 1817

Subfamily: Pteromyinae Brandt, 1855

Genus: Pliopetaurista Kretzoi, 1962

Pliopetaurista sp. (Fig. 6, 19)

Locality: AL2D

Material: 1 D4 (AL2D-295)

\section{Description:}

D4: (14.60 x 14.60): Triangular outline. The protocone is the highest cusp of the tooth, with the posterior branch higher than the anterior one. The parastyl is strong and of the same height and shape as paracone and metacone. Between the labial border of the parastyl and the paracone a small cusp, attached to the parastyl, nearly closes the valley. Protoloph and metaloph present protoconule and metaconule respectively. Both ridges are connected to the protocone. The protocone bears a small mesoloph. In the labial border, a mesostyl is present between paracone and metacone. The metaconule and the posteroloph are connected by a low lophule.

\section{Discussion:}

The genus Pliopetaurista was first described from the French locality of Perpignan (Depéret, 1897) for Sciuri- dae of large size, in which the convergence of the lophs and the well developed metaconule in the upper teeth are typical features (Mein, 1970).

Since the description of Pliopetaurista by Depéret (1897), new data have contributed to a better knowledge of the systematics, biostratigraphy and paleogeography of this genus in Europe (see Dahlmann, 2001). Nevertheless, many questions remain open, and the record of this genus in the Iberian basins is one of these issues. So far, the Iberian record of Pliopetaurista is restricted to P. pliocaenica from the localities of the Granada basin, PUR-25, PUR-24A and PUR-4 (García-Alix et al., 2007) and the localities of the Teruel basin, La Gloria-2 and Arquillo-3 (Adrover et al., 1993). Pliopetaurista sp. has also been cited in the Upper Turolian of Venta del Moro, in the Cabriel Basin (Montoya et al., 2006b). The locality AL2D has yielded only one D4, of a small-sized species. The size of this specimen and the presence of a small mesoloph on the protocone and of a mesostyl in the labial border allow to distinguish it from the large-sized species of the genus. The specimen from AL2D differs from P. kollmanni in size, greater in AL2D, and by the presence in the material from Alcoy of a more pronounced protoconule and metaconule. With respect to P. meini, it differs in the presence of a short mesoloph. Despite the presence in AL2D of a short mesoloph, similar to that of $P$. meini, the size and general morphology of this tooth resemble those of $P$. raui from Wölfersheim (Dahlmann, 2001). Based on these features and until more material becomes available, we consider this specimen as belonging to Pliopetaurista sp.

\section{General discussion}

\subsection{Faunal lists}

The faunal lists of AL2C and AL2D are given in Table 3 , and compared with Alcoy-2. The differences between AL2C and AL2D, with the presence in AL2D of Castillomys gracilis, Occitanomys brailloni, Pliopetaurista sp., Glis sp. and Blancomys sp., all of them very scarce, are attributed to the sampling effort. Both faunal assemblages are very similar to the one published by Esteban Aenlle and Lacomba for Alcoy-2 (1988).

\subsection{Biostratigraphy}

The presence of the genus Trilophomys (T. cf. castroi), accompanied by Blancomys, two species of Paraethomys, a small-sized form identified as $P$. meini and a bigger form classified as $P$. abaigari, and the presence of Eliomys intermedius, are typical features of the Ruscinian (Mein et al., 1990; Minwer-Barakat, 2005; Sesé, 2006). Moreover, the coexistence of Stephanomys cor- 
dii, Apodemus gorafensis, Apodemus atavus, Castillomys gracilis and Paraethomys meini in the same assemblage is typical of the early Ruscinian, MN14 (García-Alix et al., 2008b; Minwer-Barakat, 2005).

The Ruscinomys from the studied localities has been determined as $R$. cf. lasallei, a taxon found in MN14. Adrover et al. (1993) noted that Ruscinomys was very abundant in the middle Turolian, becoming very scarce from MN13 onwards, which seems to be the situation of AL2C and AL2D. Regarding Apocricetus, A. barrierei is typical of MN14 and replaced by $A$. angustidens which is present in both MN14 and MN15. The material from AL2D has been adscribed to $A$. aff. angustidens on biometric criteria, morphologically both species can only be distinghised on a statistical basis (Freudenthal et al., 1998).

Esteban Aenlle and Lacomba (1988) proposed a late Ruscinian age for Alcoy-2. Nevertheless, the faunal assemblage, with the presence of Castillomys gracilis and Paraethomys aff. abaigari, initially adscribed to P. jaegeri, suggests an older age (MN14) for this locality, which agrees with the inferred age for Alcoi-Mina on the basis of its macromammal assemblage (Montoya et al., 2006a).

\subsection{Paleoecology}

Micromammals have extensively been used as paleoclimatic indicators (van de Weerd, 1976; Daams et al., 1988; Montuire et al., 2006; García-Alix et al., 2008c). The ecological requirements of a number of taxons of Miocene and Pliocene age have been determined using phylogenetic affinities, dental-corporal modifications and association with other taxons of known ecological preferences (García-Alix et al., 2008c).

The rodent assemblages from AL2C and AL2D are clearly dominated by the Muridae family, with a prevalence of $81 \%$ in the former and $84 \%$ in the latter. The collection from Alcoy-2 also shows a predominance of this family, although not so pronounced as in the localities here studied. The most abundant genus is Stephanomys, followed by Paraethomys (Table 9), which comprise two species, $P$. meini and $P$. aff. abaigari. In AL2C, these two taxa represent $37.98 \%$ of the assemblage, with the same number of specimens adscribed to each of the species, whereas in AL2D and Alcoy-2 there is a clear predominance of $P$. aff. abaigari over $P$. meini. The percentages of the remaining species found in the mentioned localities are evenly matched, apart from the cricetids and insectivores in Alcoy-2 (Table 9). The faunal list published by Esteban Aenlle and Lacomba (1988) does not mention the genus Apocricetus (Table 3), although in the collection housed at the UCM this taxon represents $5.72 \%$ of the assemblage, compared with $1.26 \%$ in AL2C and 2.18 $\%$ in AL2D. Regarding the insectivores, they comprise

$\begin{array}{llll} & \text { AL2C } & \text { AL2D } & \text { Alcoy-2 } \\ \text { Apodemus } & 12.66 & 15.54 & 9.25 \\ \text { Castillomys } & 0.00 & 1.09 & 1.76 \\ \text { Paraethomys } & 39.78 & 26.18 & 18.07 \\ \text { Occitanomys } & 0.00 & 2.18 & 1.76 \\ \text { Stephanomys } & 30.38 & 40.00 & 37.00 \\ \text { Apocricetus } & 1.26 & 2.18 & 5.72 \\ \text { Blancomys } & 0.00 & 0.36 & 3.96 \\ \text { Ruscinomys } & 6.33 & 4.00 & 2.20 \\ \text { Trilophomys } & 7.59 & 4.36 & 7.49 \\ \text { Eliomys } & 2.53 & 1.82 & 3.96 \\ \text { Glis } & 0.00 & 0.36 & 1.76 \\ \text { Pliopetaurista } & 0.00 & 0.36 & 0.00 \\ \text { Soricidae Indet. } & 1.26 & 0.36 & 1.76 \\ \text { Parasorex } & 0.00 & 1.82 & 0.88 \\ \text { Asoriculus } & 0.00 & 0.00 & 4.40\end{array}$

Table 9.- Relative abundance of the genera present in the localities of AL2C, AL2D and Alcoy-2.

Tabla 9.- Abundancia relativa de los generos presentes en los yacimientos de AL2C, AL2D y Alcoy-2.

the $7.04 \%$ of all the specimens from Alcoy-2, showing a remarkable contrast with AL2C, which has yielded a single specimen, and AL2D, where just a few fragmentary remains have been found.

Regarding the paleoecologic requirements, we have used the climatic and habitat preferences proposed by García Alix et al. (2008c) for the studied taxa. So, in the faunal assemblages of AL2C and AL2D, several taxa are interpreted as warm climate indicators such as Apodemus atavus, Paraethomys meini and Apocricetus, whereas Ruscinomys and Trilophomys are associated with cold temperatures. Also, both Paraethomys meini and Ruscinomys are thought to indicate dry environmental conditions, whereas Apodemus gorafensis, Apodemus atavus, Eliomys, Pliopetaurista and Glis would point to moist paleoenvironments. In the same way, a number of the taxa present in AL2C and AL2D are considered indicators of open and herbaceous habitats, like Apocricetus, Blancomys, Ruscinomys and Trilophomys, whereas Apodemus atavus, Eliomys, Pliopetaurista and Glis are considered indicators of forested habitats. There are also several taxa which have no particular environmental requirements (eurytopic) regarding temperature, like A. atavus, Castillomys, Stephanomys, Blancomys, Eliomys and Pliopetaurista; Castillomys, Apocricetus, Blancomys, Trilophomys and Stephanomys are thought to be indifferent with respect to the humidity. Some taxa cannot be associated with a concrete habitat, like Castillomys, Paraethomys meini and Stephanomys.

Because of their scarcity in the Iberian Peninsula and palaeoecological implications, the presence of Pliopetaurista and Glis in AL2D is remarkable. Pliopetaurista is 


\begin{tabular}{cccccccccc} 
& \multicolumn{3}{c}{ HUMIDITY } & \multicolumn{3}{c}{ TEMPERATURE } & \multicolumn{3}{c}{ HABITAT } \\
Locality & Wet & Dry & Eurytopic & Cold & Warm & Eurytopic & Open & Forested & Eurytopic \\
AL2C & 16.45 & 25.32 & 39.23 & 13.92 & 26.58 & 40.50 & 15.18 & 8.86 & 59.96 \\
AL2D & 17.44 & 13.82 & 49.81 & 8.72 & 20.36 & 51.99 & 10.90 & 8.72 & 61.45 \\
Alcoy-2 & 21.13 & 8.37 & 56.81 & 11.45 & 23.78 & 51.08 & 19.37 & 11.88 & 55.06
\end{tabular}

Table 10.- Relative abundance of the taxa from the studied localities according to their ecological preferences. The taxa with unknown preferences are not shown.

Tabla 10.- Abundancia relativa de los taxones de los yacimientos estudiados según sus preferencias ecológicas. No se muestra los taxones con preferencias desconocidas.

recognized as a member of the flying squirrels, one of the three adaptative types found among the sciurids (de Bruijn, 1999). This group is considered arboreal and nocturnal by several authors (Cuenca-Bescós, 1988; de Bruijn, 1999; García-Alix, 2006; García-Alix et al. 2008c). Also, van Dam and Weltje (1999) assumed a preference for close, humid biotopes in accordance with the lifestyle of their extant relatives and the fossil faunal assemblages in which they are found.

The glirids underwent a dramatic reduction in diversity during the late Vallesian in the coastal basins of Eastern Spain, being reduced to just two genera, Muscardinus and Glis in the Catalonian basins (Agustí, 1990; Sesé, 2006). This reduction is also found in the other basins of the Iberian Peninsula during the Turolian, where the surviving genera were Muscardinus and Eliomys (Sesé, 2006). In AL2D, we have a quite unusual glirid assemblage, with the presence of Eliomys and Glis in the same locality, an association that, as far as we know, has only been cited in the karstic localities of Moreda-1A and Moreda-1B (Castillo, 1990). At present times, Glis is restricted to the wet northern part of the Iberian Peninsula (Castién, 2002), whereas Eliomys spreads through the entire peninsula (Moreno, 2002). Agustí (1990) considers a wet and cold climatic affinity for the genus Glis, which according to this author would explain the particular distribution of fossil species.

The assemblages from AL2D and Alcoy-2 suggest a relatively wet environment (Table 10), whereas AL2C shows a higher abundance of taxa with dry ecological affinities, like P. meini and Ruscinomys. Also, the analysis of the faunas of the studied localities is consistent with warm temperatures (Table 10). Regarding the habitat, the taxa considered as open environment indicators are slightly more abundant that those of forested environments (Table 10), which agrees with a forest mosaic scenario.

\section{Conclusions}

According to the geologic context, we consider a probable equivalent stratigraphic position for the classic locality of Alcoy-Mina with Alcoy-2, AL2C and AL2D. The age assigned to AL2C and AL2D matches age of Alcoy-Mina proposed by Montoya et al. (2006a), who placed this locality in the Early Ruscinian (MN14).

The presence of a small form of the genus Pliopetaurista in AL2D constitutes the southernmost record of this group of squirrels, which only has been described from central Europe (Pliopetaurista raui - Dahlmann, 2001).

The presence of a form of the genus Glis in AL2D confirms the record of this taxon in the locality Alcoy-2 (Castillo, 1990).

From the fossil material yielded by the localities of AL2C and AL2D, our age interpretation agrees with the end of the Early Ruscinian (MN14) or the early-late Ruscinian boundary (MN14-MN15), by the presence of Apocricetus cf. angustidens. Assuming that Alcoy-2 and AL2C/AL2D are probably equivalent levels, our age interpretation is clearly older than that of Esteban Aenlle and Lacomba (1988), since these authors proposed an Upper Ruscinian age (MN15) for the locality of Alcoy-2.

The mixture of inhabitants of open and herbaceous habitats, like Apocricetus, Blancomys, Ruscinomys and Trilophomys, and others of forested environments like Apodemus atavus and Eliomys, is consistent with a mosaic forest scenario. Also, the presence in AL2D of a flying squirrel, Pliopetaurista sp., and a glirid with humid ecological affinities like Glis sp. suggest a wet environment. The macrofauna from Alcoy is very singular, differing from the faunal assemblages of other contemporaneous Iberian localities (Montoya et al., 2006). These authors suggested that the differences may be due to a relatively wetter environment, which agrees with the paleoenvironmental inferences made in this paper.

Regarding the temperature, both AL2C and AL2D present cold weather indicators (Trilophomys, Ruscinomys) and taxa with warm preferences (Apodemus atavus, Paraethomys meini, Apocricetus). However, the much higher relative abundance of warm climate indicators makes us consider a mild climate at the moment of the deposition of the studied sites.

\section{Acknowledgements}

We would like to thank the Valencian government for supporting this study, encompassed by the project GV06/304. We also acknowledge the funding support 
by project CGL2011-25754 of the Spanish Ministry of Science and Innovation. We thank the IGN (Instituto Geográfico Nacional), "SIOSE CInstituto Geográfico Nacional de España - <Instituto Cartográfico Valenciano $>$ for the geographic information necessary for Figure 1. We want to thank the Paleontological association "Isurus", from Alcoy, as well as all the students at the Universitat de València that have taken part in the field work. Finally we would like to express our gratitude to the Drs. María Ángeles Álvarez Sierra, Pablo Peláez Campomanes, Carolina Castillo and Elvira Martín-Suárez for their valuable help and comments. The comments and suggestions by the reviewers M. Freudenthal and A. García-Alix have been much appreciated.

\section{References}

Adrover, R. (1969): Los micromamíferos del Plioceno inferior de los lignitos de Alcoy. I. Ruscinomys. Boletín de la Real Sociedad Española de Historia Natural (Sección Geológica) 67, 245-272.

Adrover, R. (1986): Nuevas faunas de roedores en el Mio-Plioceno continental de la región de Teruel (España). Interés bioestratigráfico y paleoecológico. $\mathrm{PhD}$. Thesis, Instituto de Estudios Turolenses: $423 \mathrm{p}$.

Adrover, R., Mein, P., Moissenet, E. (1988): Contribución al conocimiento de la fauna de roedores del Plioceno de la región de Teruel. Teruel 79 (1), 89-151.

Adrover, R., Mein, P., Moissenet, E. (1993): Roedores de la transición Mio-Plioceno de la región de Teruel. Paleontologia i Evolució 26-27, 47-84.

Adrover R., Mein P. (1996): Nuevo Ruscinomys (Rodentia, Mammalia) en el Mioceno Superior de la región de Teruel (España). Estudios Geológicos 52, 361-365.

Aguilar, J.P, Calvet, M., Michaux, J. (1986): Description des rongeurs pliocènes de la faune du Mont-Hélène (Pyrénées-Orientales, France), nouveau jalon entre les faunes de Perpignan (Serrat-D'en-Vacquer) et de Sète. Paleovertebrata 16 (3), 127-144.

Aguilar, J.P., Michaux, J., Delannoy, J.J., Guendon, J.L. (1993): A Late Pliocene rodent fauna from Alozaina (Malaga, Spain). Scripta Geologica 103, 1-22.

Aguilar, J.P., Michaux, J. (2011): Pleistocene edible dormice (Rodentia Mammalia) from Slovenia, and their relations to the present day Glis glis (Linnaeus 1766). Acta Carsologica 40 (2), 369-380.

Aguirre E., Hoyos M., Morales J. (1975): Alcoy: observaciones preliminares sobre la secuencia Neógeno- Cuaternaria del Serpis. Acta Geologica Hispanica 10 (2), 75-77.

Agustí, J. (1990): The Miocene rodent succession in Eastern Spain: a zoographical appraisal. In: E.H. Lindsay et al. (eds.), European Neogene Mammal Chronology. Plenium Press, New York: 375-404.

Agustí, J., Martín-Suárez, E. (1984): El Plioceno continental de la depresión Guadix-Baza (Prov. Granada) y su fauna de micromamíferos. Nota preliminar. Acta Geologica Hispanica 19 (4), 277-281.

Ballesteros Navarro, B. J., Rodríguez Hernández, L., Hernández Bravo, J. A., López Gutiérrez, J. L., Fernández Mejuto, M., García Menéndez, O., Domínguez Sánchez, J. A., Díaz Losada, E., Castillo Pérez, E., Padilla Benítez, A., Vela Mayorga, A., Muñoz Alonso, J., Gómez Fontalva, J. (2007): Actualización y mejora del conocimiento hidrogeológico y funcionamiento de los acuíferos de Alicante. Caracterización hidrogeológica de la U. H. 08.40 (Sierra Mariola). Instituto Geológico y Minero de España, Diputación de Alicante. Tomo I: Memoria, $118 \mathrm{p}$.

Bruijn, H. de (1999): Superfamily Sciuroidea. In: Rössner, G. E. y Heis- sig, K. (eds.), The Miocene Land Mammals of Europe. Verlag Dr. Friedrich Pfeil, München: 271-280.

Castién, E., (2002): Glis glis Linnaeus 1766. In: Palomo, J.L. and Gisbert, J. (eds.), Atlas de los Mamíferos terrestres de España. Dirección General de Conservación de la Naturaleza, SECEM-SECEMU, Madrid: $428-431$.

Castillo, C. (1990): Paleocomunidades de Micromamíferos de los Yacimientos kársticos del Neógeno Superior de Andalucía Oriental. PhD. Thesis, Universidad de Granada: 225 p.

Cuenca-Bescós, G. (1988): Revisión de los Sciuridos del Aragoniense y del Rambliense en la fosa de Calatayud-Montalbán. Scripta Geologica 87, 1-116.

Daams, R. (1981): The dental pattern of the Dormice Dryomys, Myomimus, Microdyromys and Peridyromys. Utrecht Micropaleontological Bulletins, special publication 3, 1-115.

Daams, R., Freudenthal, M., van der Meulen, A.J. (1988): Ecostratigraphy of micromammal faunas from the Neogene of Spain. Scripta Geologica, Special Issue 1, 286-302.

Dahlmann, T. (2001): Die Kleinsäuger der unter-pliozänen Fundstelle Wölfersheim in der Wetterau (Mammalia: Lipotyphla, Chiroptera, Rodentia). Courier Forschungsinstitut Senckenberg Series 227, $1-129$.

Dam, J. van, Weltje, G.J. (1999): Reconstruction of the Late Miocene climate of Spain using rodent palaeocommunity successions: an application of end-member modeling. Palaeogeography, Palaeoclimatology, Palaeoecology 151, 267-305. doi: 10.1016/S0031-0182(99)00015-2

Depéret, C. (1897): Étude de quelques gisements nouveaux de vertébrés pléistocènes de l'Île de Corse. Annales de la Société Linnéenne de Lyon 44, 113-6.

Durand Delga, M., García Rodrigo, B., Magne, J., Polveche, J. (1964): À propos du Miocène de la région d'Alcoy (province d'Alicante, Espagne). Cursillos y Conferencias 9, 213-217.

Esteban Aenlle, J., Lacomba, J. I. (1988): El yacimiento de Alcoy-2. Nuevo nivel con micromamíferos del Plioceno inferior (MN15) en el área de Alcoy. Comunicacions. Col-loqui Homenatge a R. Adrover "Bioeventos y sucesiones faunisticas en el Terciario continental ibérico", Sabadell, 17.

Freudenthal, M. (2004): Gliridae (Rodentia, Mammalia) from the Eocene and Oligocene of the Sierra Palomera (Teruel, Spain). Treballs del Museu de Geologia de Barcelona 12, 97-173.

Freudenthal M., Mein P., Martín-Suárez E. (1998): Revision of Late Miocene and Pliocene Cricetinae (Rodentia, Mammalia) from Spain and France. Treballs del Museu de Geologia de Barcelona 7, 11-93.

Furió, M., Santos-Cubedo, A., Blain, H. A., Blaya, E., Casanovas-Vilar, I., Madurell, J., Martínez-Alba, D., (2005): Síntesis sobre las faunas fósiles del complejo cárstico Almenara-Casablanca (Castellón). In: G. Melendez, C. Martínez-Pérez, S. Ros, H. Botella, P. Plasencia (eds.), Miscelánea Paleontológica 6, 273-286.

García-Alix, A. (2006): Bioestratigrafía de los depósitos continentales de la transición Mio-Plioceno de la cuenca de Granada. PhD. Thesis, Universidad de Granada, 429 p.

García-Alix, A., Minwer-Barakat, R., Martín-Suárez, E., Freudenthal, M. (2007): New data on Mio-Pliocene Sciuridae (Rodentia, Mammalia) from southern Spain. Comptes Rendus Palevol 6, 269-279. doi:10.1016/j.crpv.2007.02.001.

García-Alix, A., Minwer-Barakat, R., Martín-Suárez, E., Freudenthal, M. (2008a): Cricetidae and Gliridae (Rodentia, Mammalia) from the Miocene and Pliocene of southern Spain. Scripta Geologica 136, $1-37$.

García-Alix, A., Minwer-Barakat, R., Martín-Suárez, E., Freudenthal, M. (2008b): Muridae (Rodentia, Mammalia) from the Mio-Pliocene boundary in the Granada basin (southern Spain). Biostratrigraphic and phylogenetic implications. Neues Jahrbuch für Geologie und Paläontologie Abhandlungen 248, 183-215. doi: 10.1127/00777749/2008/0248-0183. 
García-Alix, A. Minwer-Barakat, R., Martín-Suárez, E., Freudenthal, M., Martín, J.M., (2008c): Late Miocene-Early Pliocene climatic evolution of the Granada Basin (southern Spain) deduced from the paleoecology of the micromammal associations. Palaeogeography, Palaeoclimatology, Palaeoecology 265, 214-225. doi: 10.1016/j.palaeo.2008.04.005

Gervais, P. (1853). Description des ossements fossiles de mammifères rapports d'Espagne par MM. de Verneuil, Collomb et de Lorière. Bulletin de la Société géologique de France 2e série 10: 147-168, pls 3-6.

Kowalski, K. (1956). Insectivores, Bats and Rodents from the early Pleistocene bone breccia of Podlesice, near Kroczyce (Poland). Acta Palaeontologica Polonica 1 (4), 331-394.

Kowalski, K. (1963): The Pliocene and Pleistocene Gliridae (Mammalia, Rodentia) from Poland. Acta Zoologica Cracoviensia 8 (14), 533-567.

Kukal, Z. (1971): Geology of recent sediments. Central Geological Survey, Prague, $490 \mathrm{p}$.

López Martínez, N. (1989): Revisión sistemática y bioestratigráfica de los Lagomorpha (Mammalia) del Terciario y Cuaternario de España. Memorias del Museo Paleontológico de la Universidad de Zaragoza 3 (3), 1-350.

López-Martinez, N., Michaux, J., Hutterer, R. (1998): The skull of Stephanomys and a review of Malpaisomys relationships (Rodentia: Muridae): taxonomic incongruence in Murids. Journal of Mammalian Evolution 5 (3), 185-215. doi: 10.1023/A:1020508428859.

Mansino, S., Ruiz-Sánchez, F.J., Montoya, P. (2009): Estudio preliminar de las faunas pliocenas de roedores del yacimiento Alcoi Cotes Altes 2 (ACA-2, Alicante, España). Paleolusitana 1, 251-256.

Martín-Suárez, E., Mein, P. (1991): Revision of the genus Castillomys (Muridae, Rodentia). Scripta Geologica 96, 47-81.

Martín-Suárez, E., Freudenthal, M. (1993): Muridae (Rodentia) from the Lower Turolian of Crevillente (Alicante, Spain). Scripta Geologica 103, 65-118.

Martín-Suárez, E., Freudenthal, M., (1998): Biostratigraphy of the continental Upper Miocene of Crevillente (Alicante, SE Spain). Geobios 31 (6), 839-847. doi:10.1016/S0016-6995(98)80113-7

Martín-Suárez, E., Mein, P. (1998): Revision of the genera Parapodemus, Apodemus, Rhagamys and Rhagapodemus (Rodentia, Mammalia). Geobios 31 (1), 87-97. doi: 10.1016/S0016-6995(98)80099-5. ISSN: 0016-6995

Martín-Suárez, E., Freudenthal, M., Krijgsman, W., Rutger Fortuin, A., (2000): On the age of continental deposits of the Zorreras member (Sorbas basin, SE Spain). Geobios 33 (4), 505-512. doi:10.1016/ S0016-6995(00)80084-4

Mein, P. (1970): Les Sciuroptères (Mammalia, Rodentia) Neogènes d'Europe Occidentale. Geobios 3 (3), 7-77. doi: 10.1016/S00166995(70)80001-8

Mein, P., Freudenthal, M. (1971): Une nouvelle classification des Cricetidae (Mammalia, Rodentia) du Tertiaire de 1'Europe. Scripta Geologica 2, 1-37.

Mein, P., Moissenet, E., Adrover, R. (1989-1990): Biostratigraphie du Néogène Supérieur du basin de Teruel. Paleontologia y Evolució 23, 121-139.

Michaux, J. (1969): Muridae (Rodentia) du Pliocène supérieur d'Espagne et du Midi de la France. Palaeovertebrata 3, 1-25.

Minwer-Barakat, R. (2005): Roedores e insectivoros del Turoliense superior y el Plioceno del sector central de la cuenca de Guadix. $\mathrm{PhD}$. Thesis, Universidad de Granada: 606 p.

Minwer-Barakat, R., García-Alix, A., Martín-Suárez, E., Freudenthal, M. (2005): Muridae (Rodentia) from the Pliocene of Tollo de Chiclana (Granada, Southern Spain). Journal of Vertebrate Paleontology 25 (2), 426-441. doi: 10.1671/0272-4634(2005)025[0426:MRFTPO] 2.0.CO;2.

Minwer-Barakat, R., García-Alix, A., Agustí, J., Martín-Suárez, E.,
Freudenthal, M., (2009): The micromammal fauna from Negratín-1 (Guadix basin, Southern Spain): new evidence of African-Iberian mammal exchanges during the late Miocene. Journal of Paleontology 83 (6), 854-879. doi: 10.1666/09-009.1.

Montenat C. (1973): Les Formations néogènes et Quaternaires du Levant espagnol (Provinces d'Alicante et de Murcia). PhD. Thesis, Université de Orsay-Paris-Sud, $1170 \mathrm{p}$.

Montenat, C., Bruijn, H. de (1976): The Ruscinian rodent faunule from La Juliana (Murcia); its implication for the correlation of continental and marine biozones. Proceedings Koninklijke Nederlandse Akademie van Wetenschappen, B 79 (4), 245- 255.

Montoya, P., Ginsburg, L., Alberdi, M.T., Made, J. van der, Morales, J., Soria, M.D. (2006a): Fossil large mammals from the early Pliocene locality of Alcoy (Spain) and their importance in biostratigraphy. Geodiversitas 28 (1), 137-173.

Montoya, P., Morales, J., Robles, F., Abella, J., Benavent, J. V., Marín, M. D., Ruiz-Sánchez, F. J. (2006b): Las nuevas excavaciones (19952006) en el yacimiento del Mioceno final de Venta del Moro, Valencia. Estudios Geológicos 62, 313-325.

Montuire, S., Maridet, O., Legendre, S. (2006): Late Miocene-Early Pliocene temperature estimates in Europe using rodents. Palaeogeography, Palaeoclimatology, Palaeoecology 238, 247-262. doi: 10.1016/j.palaeo.2006.03.026.

Moreno, S., (2002): Eliomys quercinus Linnaeus, 1766. In: Palomo, J. L. and Gisbert, J. (eds.), Atlas de los Mamiferos terrestres de España. Dirección General de Conservación de la Naturaleza, SECEM-SECEMU, Madrid: 432-435.

Pedraza Gilsanz, J. de (1996): Geomorfología. Principios, métodos y aplicaciones. Editorial Rueda, S. L., Madrid. 414 p.

Pierson D'Autrey L. (1987): Sédimentation et structuration synsédimentaire dans le bassin néogène d'Alcoy (Cordillères Bétiques externes Orientales Espagne). PhD. Thesis, Université de Paris: 315 p.

Reumer, J.W.F., Hoek Ostende, L.W. van den (2003): Petauristidae and Sciuridae (Mammalia, Rodentia) from Tegelen, Zuurland, and the Maasvlakte (the Netherlands). In: Reumer, J.W.F. and Wessels, W. (eds.), Distribution and migration of Tertiary mammals in Eurasia. A volume in honour of Hans de Bruijn. Deinsea 10, 455-467.

Ruiz Bustos, A. (1986): Análisis del proceso evolutivo del género Stephanomys (Rodentia, Muridae). Paleomammalia 1 (1), 1-22.

Ruiz Bustos, A., Sesé, C., Dabrio, C., Peña, J.A., Padial, J. (1984): Geología y fauna de micromamíferos del nuevo yacimiento del Plioceno inferior de Gorafe-A (depresión de Guadix-Baza, Granada). Estudios Geológicos 40, 231-241.

Santisteban C. de, Montoya P., Usera J., Robles F. (1997): El Terciario marino y continental de Alicante. In: Alcalá L., Alonso A. M. (eds.), Itinerarios Geológicos del Terciario de Centro y Este de la Península Ibérica. Universidad Complutense de Madrid, Consejo Superior de Investigaciones Científicas, Madrid: 73-107.

Sesé, C. (2006): Los roedores y lagomorfos del Neógeno de España. Estudios Geológicos 62, 429-480.

Thaler L., Crusafont, M., Adrover R. (1965): Les premiers micromammifères du Pliocène d'Espagne; précisions chronologiques et biogéographiques sur la faune d'Alcoy. Comptes Rendus de l'Académie des Sciences de Paris 260, 4024-4027.

Viseras, C., Soria, J.M., Fernández, J. (2004): Cuencas Neógenas Postorogénicas de la Cordillera Bética. In: J.A. Vera, (Ed.), Geología de España, SGE-IGME, Madrid: 576-581.

Weerd, A. van de (1976): Rodent faunas of the Mio-Pliocene continental sediments of the Teruel-Alfambra region, Spain. Utrecht Micropaleontological Bulletins, special publication 2, 1-217.

Weerd, A. van de (1979): Early Ruscinian rodents and lagomorphs (Mammalia) from the lignites near Ptolemais (Macedonia, Greece). Proceedings Koninklijke Nederlandse Akademie van Wetenschappen ser. $B$ 82, 127-170. 